\title{
REKONSEPTUALISASI PERJANJIAN JUAL PUTUS TERKAIT KLAIM PENGARANG TERHADAP PEMBERLAKUAN KLAUSULA NON USE
}

\author{
Muhammad Zaki Sierrad. \\ Fakultas Hukum Universitas Widya Mataram \\ Edy Lisdiyono \\ Sigit Irianto \\ Fakultas Hukum Universitas 17 Agustus 1945 Semarang \\ Email: zakisierrad@yahoo.com
}

\begin{abstract}
Abstrak
Konsep peralihan kepemilikan hak cipta buku melalui Perjanjian jual Putus pada Sistem Hukum Hak Cipta Indonesia jelas belum memberikan ketentuan klausula Non Use. Secara substansi hukum, Para pihak dapat mengaturan peralihan Hak Cipta melalui Perjanjian Jual Putus yang disepakati dan ditandatangani para pihak. Namun dalam praktek, perjanjian yang telah dibuat sama sekali juga tidak mencantumkan klausula Non Use tersebut. Jika terjadi sengketa pelaksanaan perjanjian Jual Putus, dimana Pengarang melakukan klaim diberlakukannya klausula Non Use terhadap Penerbit yang mendiamkan manuskrip dalam keadaan semula, maka Pengadilan dapat menggunakan asas-asas perjanjian, kepantasan dan kebiasaan sebagaimana diatur dalam Pasal 1339 KUH Perdata Jo. Pasal 1601 KUH Perdata, sebelum lahir peraturan perundang-undangan khusus tentang Hukum Kontrak Hak Cipta Indonesia. Rekonseptualisasi Peralihan kepemilikan hak cipta buku melalui Perjanjian Jual Putus belum memberikan perlindungan hukum yang optimal bagi para pihak, maka secara yuridis dapat diusulkan rekonseptualisasi.
\end{abstract}

Kata kunci : Non User, Perjanjian, Rekonseptualisasi

\begin{abstract}
The concept of transfer of book copyright ownership through a sold flat agreement in the Indonesian Copyright Law System clearly has not provided provisions for a Non-Use clause. In legal substance, the parties can arrange the transfer of Copyright through a sold flat agreement which is agreed upon and signed by the parties. However, in practice, the agreement that has been made also does not include the Non Use clause. If there is a dispute over the implementation of the sold flat agreement, where the Author claims the application of the Non-Use clause against the Issuer who keeps the manuscript in its original state, the Court can use the basic principles of agreement, appropriateness and customs as regulated in Article 1339 of the Civil Code Jo. Article 1601 of the Civil Code, prior to the birth of specific laws and regulations on Indonesian Copyright Contract Law. Reconceptualization The transfer of book copyright ownership through the Sold Flat Agreement has not provided optimal legal protection for the parties, so juridically, reconceptualization can be proposed.
\end{abstract}

Keywords: Non User, Agreement, Reconceptualization

\section{A. PENDAHULUAN}

Cara menemukan isu hukum yang dihadapai anggota masyarakat dapat ditemukan melalui apa saja. Mesin pencari web ${ }^{1}$ salah satunya. Mesin pencari yang selama ini ada

1 Mesin pencari web atau mesin telusur web (bahasa Inggris: web search engine) adalah program komputer yang dirancang untuk melakukan pencarian atas berkas-berkas yang tersimpan dalam layanan www, ftp, publikasi milis, ataupun news group dalam sebuah ataupun sejumlah komputer peladen dalam suatu jaringan. Mesin pencari merupakan perangkat penelusur informasi dari dokumen-dokumen yang tersedia. Hasil pencarian umumnya ditampilkan dalam bentuk daftar yang sering kali diurutkan menurut tingkat akurasi ataupun rasio pengunjung atas suatu berkas yang disebut sebagai hits. Informasi yang menjadi target pencarian bisa terdapat dalam berbagai macam jenis berkas seperti halaman situs web, gambar, ataupun jenis-jenis berkas lainnya. Beberapa mesin pencari juga diketahui melakukan pengumpulan informasi atas data yang tersimpan dalam suatu basis data ataupun direktori web. Sebagian besar mesin pencari dijalankan oleh perusahaan swasta yang menggunakan algoritme kepemilikan dan basis data tertutup, diantaranya yang paling populer adalah safari Google (MSN Search dan Yahoo!). https://id.wikipedia.org/wiki/Mesin_pencari_web 
adalah merupakan tempat yang paling efektif untuk menemukan persoalan riil kehidupan masyarakat. Masyarakat dapat menjumpai percakapan di media sosial yang sarat dengan persoalan hukum yang membutuhkan solusi hukum yaitu dengan menemukan hukum, asas-asas hukum dan doktrin-doktrin hukum untuk memberikan jawaban atas permasalahan hukum yang ada di masayarakat.

Salah satu permasalahan hukum muncul di Kompasiana, salah satu blog citizen media. Fakta hukumnya adalah terkait keluhan Pengarang yang merasa kehilangan harapan mendapatkan keuntungan komersial dari peristiwa perdata yang dilakukannya melalui perjanjian Jual Putus dengan penerbit buku. Kompasiana mengetengahkan adanya fenomena yang ditulis yaitu: "beberapa hari lalu, aku membaca tulisan di sebuah grup. Penulis curhat, naskahnya telah disetujui oleh penerbit dengan sistem jual-putus, tapi sudah setahun lebih buku itu tak jua terbit. Meskipun telah mendapat uang pembayaran, tapi sebagai penulis ia merasa tak puas sebelum melihat karyanya mejeng di rak toko buku. Beberapa orang berkomentar itulah resiko jual-putus, penulis tak bisa berbuat apa-apa setelah naskah dibeli. Dari situ muncul pertanyaan, benarkah Jual Putus (disebut juga flat) selalu merugikan penulis?" 2

Tulisan di Kompasiana tersebut secara jelas menggambarkan informasi suatu peristiwa yang dapat menjadi issue hukum yang menarik. Disamping itu setelah membaca sepanjang tulisan, belum dapat diketemukan kajian tuntas terkait solusi yang diberikan penulis Kompasiana baik secara kebiasaan dan kepantasan dalam industri penerbitan maupun berdasarkan kajian hukumnya. Hal menarik lainnya adalah penulis di Kompasiana memunculkan istilah Jual putus (disebut juga flat) dan ini merupakan istilah yang diatur dalam Pasal 18 Undang-Undang Nomor 28 Tahun 2014 Tentang Hak Cipta (selanjutnya disebut UUHC). Sebagai norma yang sudah diatur secara posistif dalam UUHC seharusnya sudah merupakan hal yang baku dan menjadi ketentuan yang mampu mengatasi peristiwa sebagaimana substansi pengaturannya. Namun faktanya, masih ada keluhan penulis Kompasianan dengan menyebut sebagai merugikan penulis.

Secara filosofis dalam upaya untuk melindungi kepentingan pengarang yang dalam praktek tidak mendapatkan perlindungan hak hanya mendapatkan pembayaran satu kali dan mendatar atau flat dengan kondisi Hak Ekonominya telah beralih selama-lamanya, tanpa batas waktu. Secara Yuridis, hak dan kewajiban Pengarang dengan Penerbit sudah memperoleh landasan Yuridis dalam perjanjian Jual Putus yang disepakati para pihak. Namun kemudian, demi tujuan memberikan perlindungan Hak kepada Pengarang lebih kuat, maka Negara kemudian melakukan eksetrnalisasi fenomena tersebut ke dalam Pasal 18 UUHC. Namun secara sosiologis, perjanjian jual putus yang banyak dibuat, tidak selesai permasalahannya dengan memberikan perlindungan Hak Pengarang dalam kalimat terakhir Pasal 18 UUHC, yaitu: "Hak Ciptanya beralih kembali kepada Pencipta pada saat perjanjian tersebut mencapai jangka waktu 25 (dua puluh lima) tahun".

Salah satu contoh persoalan dalam perjanjian Jual Putus sebelum mencapai jangka waktu 25 (dua puluh lima) tahun adalah adanyan keluhan dalam tulisan di Kompasiana tersebut, yaitu Penerbit tidak segera menerbitkan tulisan Pengarang setelah perjanjian ditanda tangani, sedangkan perjanjian tidak memngaturnya. Isu hukum terkaitnya adalah ketentuan-ketentuan hukum manakah yang relevan dengan fakta hukum tersebut? Apakah perjanjian Jual putus yang telah dibuat dan ditandatangani para pihak yang didalamnya tidak memuat ketentuan tentang keharusan penerbit untuk segera menerbitkan buku dari manuskrip yang sudah diserahkan pengarang kepada penerbit dijadikan satu-satunya ketentuan yang mengikat ataukah Pengarang harus sabar menunggu saat perjanjian

2 Jual Putus dengan penerbit buku. Kompasiana mengetengahkan adanya fenomena, https://www.kompasiana.com/kubuside/5528f3d16ea834e24f8b4595/royalti-atau-jualputus-putuskansetelah-baca-ini 
mencapai waktu 25 (dua puluh lima) tahun. Hal ini juga didukung dengan ketentuan asas pacta sunt servanda, yaitu bahwa Perjanjian yang dibuat secara sah dapat menjadi undangundang yang mengikat para pihak. Sesuai dengan Pasal 1338 KUH Perdata.

Dalam tulisan di Kompasiana tersebut juga mengandung isu hukum dimana jika dalam Perjanjian Jual Putus tidak mengatur ketentuan yang melarang Penerbit yang tidak segera menerbitkan dalam bentuk buku atas manuskrip yang sudah diserahkan, mengandung konsep Pengarang tidak bisa melakukan upaya hukum apapun dan itu adalah resiko model jual putus. Faktanya, UUHC tidak memberikan aturan tentang klausula non use. Apakah ada asas-asas hukum yang dapat menjadi solusi dari fakta hukum dalam Perjanjian Jual Putus tidak mengatur ketentuan yang melarang Penerbit yang tidak segera menerbitkan dalam bentuk buku atas manuskrip yang sudah diserahkan.

\section{B. TELAAH KONSEP}

Perjanjian Jual Putus berlaku sebagai undang-undang bagi para pihak yang membuatnya. Hal tersebut mendapatkan penegasan berdasarkan Pasal 1338 KUH Perdata yang menegaskan bahwa: "Semua persetujuan yang dibuat secara sah berlaku sebagai undang-undang bagi mereka yang membuatnya". Dalam praktek perjanjian Jual Putus yang beredar di Indonesia tidak mengatur klausul yang mewajibkan Penerbit untuk segera menggunakan manuskrip untuk diterbitkan menjadi buku. Hal ini jelas-jelas merugikan Pengarang, karena pengarang memiliki tujuan utama agar naskah asli tersebut segera diterbitkan.

Berdasarkan wawancara dengan Pengarang ghost writer, mereka menjual putus Hak Cipta atas tulisannya selain untuk mendapatkan sejumlah uang juga agar masyarakat segera dapat membaca gaya bahasa dan alur pemikiran pengarang, sehingga menjadikan masyarakat suka. Harapan Pengarang adalah akan segera menulis judul berikutnya, yang gaya bahasa dan alur pemikirannya sudah dinikmati masyarakat dan akhirnya akan dinantikan masyarakat pembaca dan suatu saat dimasa depan karya cipta pengarang bisa menjadi best seller. Keinginan Pengarang tersebut sirna manakala Penerbit yang sudah membeli karya ciptanya tidak segera menerbitkannya, dengan alasan dan pemikiran bahwa karya cipta tersebut sudah menjadi miliknya berdasarkan perjanjian Jual Putus yang telah ditandatanganinya.

Alasan dan pemikiran Penerbit tersebut sejalan dengan konsep perjanjian Jual putus sendiri diatur dalam Penjelasan Pasal 18 UUHC, yaitu: "Jual putus adalah perjanjian yang mengharuskan Pencipta menyerahkan Ciptaannya melalui pembayaran lunas oleh pihak pembeli sehingga hak ekonomi atas Ciptaan tersebut beralih seluruhnya kepada pembeli tanpa batas waktu, atau dalam praktek dikenal dengan istilah sold flat'. Dari Penjelasan Pasal 18 UUHC, Penerbit yang sudah membayar lunas karya cipta memberikan kewajiban Pencipta untuk menyerahkan ciptaannya, sehingga hak Ekonomi atas Ciptaan tersebut beralih seluruhnya kepada pembeli tanpa batas waktu. Demikianlah konsep perjanjian Jual Putus yang dianut UUHC, sehingga menurut alasan dan pemikiran penerbit, hak kepemilikan Hak Cipta sudah beralih kepada Penerbit sejak diserahkan oleh Pengarang. Penerbitlah sekarang yang berkedudukan sebagai pemilik Hak Ekonomi atas Ciptaan seluruhnya dan selamanya tanpa batas waktu. Hal ini sesuai dengan ketentuan Pasal 1 Angka 4 UUHC, yaitu Pemegang Hak Cipta adalah pencipta sebagai pemilik Hak Cipta, pihak yang menerima hak tersebut secara sah dari pencipta atau pihak lain yang menerima lebih lanjut hak dari pihak yang menerima hak tersebut secara sah.

Lebih lanjut menurut Elyta Ras Ginting dalam bukunya menyatakan bahwa pemegang Hak Cipta terbagi menjadi dua, yakni: ${ }^{3}$

${ }^{3}$ Elyta Ras Ginting, Hukum Hak Cipta Indonesia Analisis dan Praktik, Jakarta: Citra Aditya Bakti, 2012, hlm. 183. 
1. Pemegang Hak Cipta Berdasarkan Peristiwa Hukum

Undang-Undang Hak Cipta, mengatur mengenai cara pengalihan Hak Cipta melalui suatu peristiwa hukum seperti yang diatur di dalam Pasal 16 ayat (2) Undang-Undang Hak Cipta yaitu Hak Cipta dapat dialihkan atau beralih baik seluruhnya atau sebagian karena pewarisan, hibah, wakaf, wasiat, perjanjian tertulis atau sebab lainnya sesuai dengan peraturan perundang-undangan. Selain melalui cara yang disebutkan dalam Pasal 16 ayat (2), pemegang Hak Cipta dapat pula memberikan izin kepada pihak lain untuk melaksanakan Hak Cipta dan hak terkait atas suatu ciptaan berdasarkan perjanjian lisensi seperti yang diatur dalam Pasal 80 Undang-Undang Hak Cipta.

2. Pemegang Hak Cipta Berdasarkan Undang-Undang

Berdasarkan Undang-Undang Hak Cipta juga mengenal konsep kepemilikan Hak Cipta berdasarkan undang-undang yang diatur dalam pasal 37, pasal 38 dan pasal 39 Undang-Undang Hak Cipta. Dalam hal ini negara atau badan hukum seperti penerbit dan produser rekaman dianggap sebagai pemegang Hak Cipta secara hukum dalam hal sebagai berikut:

a. Pencipta tidak diketahui jati dirinya atau tidak dikenal,

b. Pencipta tidak ingin jati dirinya diketahui atau pencipta yang menggunakan nama samaran, Ciptaan-ciptaan berupa ekspresi budaya tradisional, Ciptaan yang belum diterbitkan dan tidak diketahui siapa pencipta atau penerbitnya.

Sebagai Pemegang kepemilikan Hak Ekonomi Ciptaan berdasarkan Pasal 570 KUH Perdata yang menegaskan bahwa: Hak milik adalah hak untuk menikmati kegunaan sesuatu kebendaan dengan leluasa, dan untuk berbuat bebas terhadap kebendaan itu dengan kedaulatan sepenuhnya, asal tidak bersalahan dengan undang-undang atau peraturan umum yang ditetapkan oleh suatu kekuasaan yang berhak menetapkannya, dan tidak mengganggu hak-hak orang lain; kesemuanya itu dengan tak mengurangi kemungkinan akan pencabutan hak itu demi kepentingan umum berdasar atas ketentuan undang-undang dan dengan pembayaran ganti rugi.

Dengan demikian berdasarkan kewenangan sebagai pemegang Hak Milik, maka Penerbit bebas untuk berbuat dan tidak berbuat atas hak-hak yang terkandung dalam Hak Ekonomi suatu Ciptaan, sebagaimana dinyatakan dalam Pasal 9 ayat (1) UUHC menegaskan: "Pencipta atau pemegang Hak Cipta sebagaimana dimaksud dalam Pasal 8 memiliki hak ekonomi untuk melakukan:

a. Penerbitan Ciptaan;

b. Penggandaan Ciptaan dalam segala bentuknya;

c. Penerjemahan Ciptaan;

d. Pengadaptasian, pengaransemenan, atau pentransformasian Ciptaan;

e. Pendistribusian Ciptaan atau salinannya;

f. Pertunjukan Ciptaan;

g. Pengumuman Ciptaan;

h. Komunikasi Ciptaan; dan

i. Penyewaan Ciptaan."

Penerbitan Ciptaan yang merupakan salah satu Hak Ekonomi berdasarkan Pasal 9 ayat (1) UUHC merupakan tujuan dan alasan utama Pengarang untuk melakukan perjanjian Jual Beli dan berharap segera dieksekusi oleh Penerbit. Namun di dalam perjanjian Jual Putus tersebut tidak ada klausul yang mengatur kewajiban untuk segera menerbitkan dan tidak ada klausul yang melarang Penerbit yang tidak menerbitkan karya Pengarang dalam bentuk buku.

Rekonseptualisasi diartikan sebagai upaya konsep ulang secara konstruktif dan sistematis, sehingga konsep tersebut dapat dipergunakan untuk memahami suatu hal-hal yang mendasar dalam hukum dan juga mengenai peristiwa, perbuatan dan keadaan hukum 
yang ada dalam hukum atau sistem hukum. Istilah konsep berasal dari bahasa latin conceptum, artinya sesuatu yang dipahami. Konsep adalah pembawa arti. istilah konsep tersebut akan diketemukan arti dan batasan makna terhadap "sesuatu". Rekonseptualisasi dapat diartikan sebagai mengkonsep kembali konsep Perjanjian Jual Putus yang mengalihkan kepemilikan Hak Cipta, sebagaimana diatur dalam Pasal 18 UUHC agar dapat memberikan manfaat dan kebahagiaan bagi masyarakat.

Relevansi rekonseptualisasi atas konsep-konsep hukum yang ada dalam UUHC, yang dimaksudkan untuk memberikan solusi terhadap kenyataan hukum yang terjadi di dalam masyarakat terkait tidak ada perlindungan hak terhadap pengarang, akan tetapi jika tidak dikelola dengan baik dengan melibatkan Negara maka diprediksi akan terjadi banyak persoalan-persolan khususnya dalam pelaksanaan perjanjian Jual Putus sebagaimana telah diatur dalam Pasal 18 UUHC.

Pasal 18 UUHC dalam banyak aspek memiliki berbagai kelemahan dan kesalahan konsep. Konsep yang ada jika dikaitkan dengan asas-asas hukum kebendaan, asas-asas hukum perjanjian terlihat tidak saling mendukung dan bahkan bertentangan satu sama lain, juga tidak mengakomodir kebiasaan dan kepatutan yang berkembang di masayarakat nasional maupun internasional. Idealnya, konsep dalam Pasal 18 UUHC, misalnya konsep Jual Putus, konsep peralihan seluruh hak ekonomi, konsep 25 tahun harus dikembalikan tersebut adalah tidak boleh bertentangan dengan asas-asas hukum kebendaan, asas-asas hukum perjanjian dan bertentangan dengan kebiasaan dan kepatutan. Oleh karena itu rekonseptualisasi Pasal 18 UUHC menjadi penting dilakukan.

Untuk kepentingan rekonseptualisasi tersebut, maka disamping teori-teori, dalam penelitian ini juga dibahas mengenai konsep-konsep dan asas-asas dalam sistem hukum. Konsepsi adalah suatu bagian terpenting dari teori. Peranan konsepsi dalam penelitian ini untuk menghubungkan teori dan observasi, antara abstraksi dan kenyataan. Konsep diartikan sebagai kata yang menyatukan abstraksi yang digeneralisasikan dari hal hal yang khusus yang disebut defenisi operasional. Rekonseptualisasi Pasal 18 UUHC adalah mengkonsep ulang bagian terpenting dalam pasal tersebut, sehingga ada benag merah yang saling menghubungkan abstraksi dengan kenyataan. Tujuannya akhirnya adalah agar tercipta hukum peralihan kepemilikan Hak Cipta yang diatur dalam UUHC yang sesuai dengan teori, asas-asas, kebiasaan dan kepatutan dalam pergaulan kehidupan dan sesuai dengan undang-undang di Negara tempat Hak Cipta itu dahulu mengalir ke seluruh dunia. Jika membiarkan Pasal 18 UUHC tersebut apa adanya, maka dikhawatirkan akan terjadi banyak persoalan dalam pelaksanaan perjanjian Jual Putus dalam praktek.

Oleh karena itulah, pentingnya Pasal 18 UUHC tidak dilihat apa adanya, melainkan harus ditinjau dan dipaparkan dengan menggunakan kerangka pemikiran yang berisi tentang asas-asas konsepsi-konsepsi, teori-teori, pandangan-pandangan, penemuanpenemuan yang relevan dengan pokok permasalahan. ${ }^{4}$ Pentingnya penggunaan teori dalam suatu penelitian melalui kerangka pemikiran yang didalamnya juga terdapat teori atau kerangka teoritis mempunyai kegunaan antara lain, yaitu untuk lebih mempertajam atau lebih mengkhususkan fakta yang hendak diselidiki atau diuji kebenarannya. ${ }^{5}$ Teori juga berguna untuk memberi kerangka orientasi untuk analisis dan klasifikasi fakta-fakta ${ }^{6}$, dalam rangka mendalami konsep-konsep dalam Pasal 18 UUHC.

\footnotetext{
2010, hlm. 92

${ }^{5}$ Setiono, Pemahaman Terhadap Metodologi Penelitian Hukum, Pogram Studi Ilmu Hukum Pascasarjana Universitas Sebelas Maret Surakarta, 2010, hlm. 10-11.

${ }^{6}$ Mattulada, Studi Islam Kontemporer (Sintesis Pendekatan Sejarah, Sosiologi dan Antropologi dalam Mengkaji Fenomena Keagamaan), dalam Taufik Abdullah dan M. Rusli (ed), Metodologi Penelitian Agama Sebuah Pengantar, Tiara Wacana,Yogyakarta, 1990, hlm. 4.
}

${ }^{4}$ Mukti Fajar, Dualisme Penelitian Hukum Normatif \& Empiris, Pustaka Pelajar, Yogyakarta, 
Pemahaman mendalam terhadap konsep-konsep hukum dan asas-asas dalam hukum juga sangat penting untuk upaya rekonseptualisasi Pasal 18 UUHC ini. Konsep atau pengertian dalam bidang hukum itu disebut sebagai konsep yuridis (legal concept) tentang sesuatu, baik yang sudah dinyatakan dalam suatu pasal undang-undang, maupun di dalam doktrin. Konsep yuridis yaitu konsep konstruktif dan sistematis yang digunakan untuk memahami suatu hal-hal yang mendasar dalam hukum dan juga mengenai peristiwa, perbuatan dan keadaan hukum yang ada dalam hukum atau sistem hukum. Dengan demikian tentunya di dalam Pasal 18 UUHC sudah terdapat dan masih sangat membutuhkan tambahan konsep di dalam hukum dan Ilmu Hukum.

Sedangkan asas hukum bukanlah suatu peraturan, namun seperti yang dikatakan oleh Scholten, ${ }^{7}$ bahwa hukum tidak dapat dipahami dengan baik tanpa asas-asas (doch geen rechts is te begrijpen zonder die beginselen). Asas merupakan pokok-pokok pikiran yang melandasi dan melatarbelakangi setiap ketentuan perundang-undangan maupun putusan pengadilan di dalam sistem hukum. Asas hukum mempunyai dua landasan, yaitu: pertama, asas hukum itu berakar dalam kenyataan masyarakat dan kedua, pada nilai-nilai yang dipilih sebagai pedoman oleh kehidupan bersama. Penyatuan faktor riil dan ideal hukum ini merupakan fungsi asas hukum. ${ }^{8}$ Fungsi asas hukum dalam hukum menurut Klanderman, bersifat mengesahkan dan mempunyai pengaruh normatif dan mengikat para pihak. Mengenai fungsi asas hukum, J.J.H. Bruggink mengemukakan bahwa asas hukum mempunyai fungsi ganda yaitu sebagai fondasi dari sistem hukum positif dan sebagai batu uji kritis terhadap sistem hukum positif.'

Menurut Paton, asas hukum merupakan "jantungnya" peraturan hukum, karena: pertama, asas hukum merupakan landasan yang paling luas bagi lahirnya suatu peraturan hukum; kedua, asas hukum juga dapat disebut sebagai alasan bagi lahirnya peraturan hukum (rasio legis) dari peraturan hukum. Selanjutnya Paton mengemukakan bahwa asas hukum itu mengawal dan memberi daya hidup (nourishment) kepada hukum dan bagianbagian atau bidang-bidang dari hukum. Melalui kerangka pemikiran dalam artikel ini, maka peran teori-teori, konsepsi-konsepsi, dan asas-asas yang disusun melalui pembagian grand theory, middle range theory dan applied range theory diharapkan mampu menjawab permasalahan yang diajukan dalam artikel ini secara ilmiah. Penelitian ini akan mempergunakan Teoriteori, konsep-konsep, dan asas-asas untuk menjembatani kompleksitas permasalahan yang muncul dalam penelitian yang bertujuan untuk menjawab permasalahan disertasi yang diajukan.

Di dalam mengkaji Pasal 18 UUHC yang memiliki pertentangan konsep di dalamnya dapat juga merujuk pada Teori Sistem Lawrence Friedman, dimana di dalam mengkaji hukum sebagai sebuah sistem dalam operasinya harus memiliki tiga komponen yang saling berinteraksi, yaitu struktur (structure), substansi (substance) dan kultur (culture). Struktur hukum adalah kelembagaan yang diciptakan oleh sistem hukum. Substansi hukum dimaknai sebagai peraturan hukum substantif dan peraturan hukum tentang bagaimana seharusnya lembaga-lembaga yang diciptakan oleh peraturan hukum substantive berperilaku. ${ }^{10}$ Sedangkan kultur dipahami sebagai dukungan sosial atas hukum seperti kebiasaan, pandangan, cara berperilaku dan berpikir, yang menggerakkan dukungan masyarakat untuk mematuhi atau tidak mematuhi aturan. ${ }^{11}$ Yang hendak diuraikannya

${ }^{7}$ Paul Scholten dalam Satjipto Rahardjo, Ilmu Hukum, Bandung, Penerbit PT Citra Aditya Bakti, 2012, hlm. 128.

${ }^{8}$ Lihat Nieuwenhuis dalam Sudikno Mertokusumo, Op.Cit.,hlm.6.

${ }^{9}$ JJ.H. Bruggink, Rechts-reflecties diterjemahkan oleh Arief Sidharta, Refleksi Tentang Hukum, Pengertian-Pengertian Dasar dalam Teori Hukum, Cetakan ketiga, Citra Aditya Bakti, Bandung 2011, hlm. 133.

${ }^{10}$ Ibid., hlm. 25.

${ }^{11}$ Ibid., hlm. 14. 
dengan teori Lawrence Friedman itu tidak lain adalah bahwa dasar semua aspek dalam sistem hukum itu adalah budaya hukum. Budaya adalah kumpulan nilai-nilai yang baik dalam masyarakat yang menjadi kebiasaan dan ini cocok dengan Pasal 1339 KUH Perdata yang menegaskan bahwa perjanjian tidak saja mengikat untuk hal-hal yang dengan tegas dinyatakan di dalamnya, tetapi juga untuk segala sesuatu yang menurut sifat perjanjian diharuskan oleh kepatutan, kebiasaan atau undang-undang. Juga berdasarkan Pasal 1601 KUH Perdata di bawah Bab Ketujuh A, bagian kesatu ketentuan umum, yang menyatakan: Selainnya persetujuan-persetujuan untuk melakukan sementara jasa jasa yang diatur oleh ketentuan-ketentuan yang khusus untuk itu dan oleh syarat-syarat yang diperjanjikan, dan jika tidak ada, oleh kebiasaan, maka adalah dua macam persetujuan dengan mana pihak yang satu mengikatkan dirinya untuk melakukan pekerjaan bagi pihak yang lainnya dengan menerima upah: persetujuan perburuhan dan pemborongan pekerjaan.

Dalam ketentuan Pasal 1601 KUH Perdata tersebut sebetulnya mengandung pesan, bahwa terhadap perjanjian Jual Putus haruslah dibuatkan ketentuan-ketentuan khusus untuk itu, oleh syarat-syarat yang harus diperjanjian dan jika tidak ada dapat menggunakan sumber kebiasaan. Dengan demikian untuk sementara dapat diperoleh kesimpulan bahwa dalam pembuatan perjanjian Jual Putus yang merupakan suatu bentuk perjanjian jenis baru yang pelaksanaannya dapat tunduk pada aturan: (1) Buku III KUH Perdata, yang juga memuat ketentuan tentang Perjanjian Jual Beli yang dalam banyak hal dapat dijadikan sandaran awal untuk pembuatan Perjanjian Jual Putus Hak Cipta, (2) ketentuan-ketentuan yang khusus yang harus dibuat untuk itu seperti misalnya perjanjian waralaba (3) oleh syarat-syarat yang timbul dari perjanjian dan (4) kebiasaan.

Akhirnya, Teori Sistem Sudikno Mertokusumo dan Lawrence Friedman dimaksudkan untuk dipergunakan dalam menemukan faktor-faktor yang menyebabkan perlindungan hak para pihak dalam peralihan kepemilikan Hak Cipta, yang walaupun sudah diatur dalam Pasal 18 UUHC dan juga diatur dalam perjanjian Jual Putus antara Pencipta dan Penerbit, namun dalam prakteknya masih belum memberikan perlindungan yang seimbang atas hak-hak para pihak. Permasalahan yang menyangkut rekonseptualisasi perjanjian Jual Putus yang mengalihkan pemilikan Hak Cipta akan dikaji dengan menggunakan teori sistemnya Sudikno Mertokusumo yang didukung oleh Teori sistemnya Lawrence Friedman dengan prinsip satu sama lain harus saling memberikan manfaat/utility berdasarkan Teori Utilitarianisme Jeremy Bentham, dimana pada prinsipnya menegaskan agar peralihan kepemilikan Hak Cipta dapat terjamin secara hukum maka hakhak para pihak akan mendapatkan perlindungan haknya, baik dengan pengaturan oleh hukum yang hidup ( living law) dan tentu saja di dalam UUHC dan KUH Perdata sebagai law in books.

\section{METODE PENELITIAN}

Permasalahan di atas akan dikaji dengan menggunakan metode yuridis empiris yaitu suatu metode penelitian untuk meneliti suatu gejala yang timbul dimasyarakat ${ }^{12}$, dengan melalui pendekatan preskriptif analitis. Penelitian ini mengunakan data primer dan data sekunder yaitu data yang diperoleh dari lapangan dan data yang bersumber dari perundang-undang dan peraturan-peraturan lain yang berhubungan dengan hukum kebendaan dan hukum Perjanjian. Secara empiris melakukan wawancara bebas dengan Pengarang dan Penerbit yang didasarkan pada Perjanjian Jual Putus yang telah ada.

\section{PEMBAHASAN}

${ }^{12}$ Munir Fuady , Metode Riset hukum, Pendekatan Teori dan Konsep, Rajawali Pers, Depok, 2018, hlm. 130 


\section{Pengaturan Perjanjian Jual Putus dalam Sistem Hukum.}

Berbagai hal dan permasalahan dalam Hukum Perjanjian Jual Putus Hak Cipta di Indonesia harus segera di susun. Perjanjian Jual Putus yang dibuat Pengarang dan Penerbit belum mendasarkan pada hukum yang berlaku dikarenakan tidak secara sistematis memperhatikan konsep-konsep dan asas-asas Hukum Benda dan Hukum Perjanjian serta tidak jelas menginduk kepada sistem hukum Common Law atau Civil Law. Hasil penelusuran terhadap perjanjian Jual Putus yang ada dalam praktek menunjukkan bahwa secara prinsip telah masuk dalam kategori sebuah perikatan yang lahir dari kontrak, sebagaimana diatur dalam Bab II Buku III Kitab Undang-Undang Hukum Perdata (KUH Perdata) Indonesia. Dalam Bab II Buku III KUH Perdata tersebut menegaskan adanya istilah perikatan yang lahir dari kontrak, dengan menyebutkan "Tentang perikatanperikatan yang dilahir dari kontrak atau persetujuan".

Pengertian kontrak sendiri tidak ditemukan dalam KUH Perdata, sedangkan pengertian tentang persetujuan diatur dan ditegaskan dalam Bagian Kesatu, Ketentuan Umum dalam Pasal 1313 KUH Perdata, yaitu: Suatu persetujuan adalah suatu perbuatan dengan mana satu orang atau lebih mengikatkan dirinya terhadap satu orang lain atau lebih.

Istilah Persetujuan dalam hukum perjanjian merupakan kesepadanan dari istilah Overeenskomst dalam bahasa Belanda, atau Agreement dalam bahasa Inggris. ${ }^{13}$ Di dalam sistem Common Law ada pembedaan antara contract dan agreement. Semua kontrak adalah agreement, tetapi tidak semua agreement adalah kontrak. ${ }^{14}$ Hukum kontrak semata-mata dimaksudkan sebagai hukum yang mengatur tentang perjanjian-perjanjian yang prestasinya dilakukan oleh kedua belah pihak. ${ }^{15}$ Dalam konteks maka Perjanjian Jual Putus adalah sebuah kontrak, karena prestasinya dilakukan oleh kedua belah pihak, dimana pihak satu mengajukan penawaran (offer) dan pihak lainnya menerima penawaran tersebut (acceptance).

Pasal 1313 KUH Perdata memberikan pengertian perjanjian sebagai suatu perbuatan yang terjadi antara satu orang atau lebih mengikatkan dirinya terhadap orang lain. Pasal ini memberikan bukti bahwa sebetulnya perjanjian adalah sebagai agreement yang juga merupakan kontrak, walaupun kemudian ada kontrak, khususnya perjanjian dua pihak yang kemudian tidak dapat dimasukkan dalam pengertian pasal 1313 KUHPerdata tersebut, misalnya perjanjian yang masuk hukum warisan. Bukti berikutnya bahwa tidak selalu kontrak sama dengan perjanjian atau agreement adalah istilah kebebasan berkontrak tidak selalu bisa dikatakan sebagai kebebasan berperjanjian.

Dalam upaya mempertegas definisi perjanjian sehingga mencakup baik perjanjian sepihak atau dua pihak, maka Pasal 6:213 ayat (1) Kitab Undang-Undang Hukum Perdata Belanda (BW Baru) memberikan batasan perjanjian sebagai suatu perbuatan hukum yang terjadi antara satu orang atau lebih mengikatkan dirinya kepada satu orang atau lebih dimana keduanya saling mengikatkan dirinya. ${ }^{16}$

Dalam Bagian Kesatu, Ketentuan Umum dari BAB II dalam Buku III ini diakhiri oleh ketentuan Pasal 1319 KUH Perdata yang memberikan ketentuan untuk mengatur munculnya perjanjian jenis baru, yaitu persetujuan yang tidak terkenal dengan suatu nama tertentu seperti halnya dengan Perjanjian Jual Putus ini. Pasal 1319 KUH Perdata secara lengkap berbunyi: Semua perjanjian, baik yang mempunyai nama khusus maupun yang

${ }^{13}$ Munir Fuady, , Op.Cit., hlm. 2

${ }^{14}$ Walter Woon, Basic Business Law in Singapore, Prentice Hall, New York, 1995, hlm. 27.

${ }^{15}$ Munir Fuady, Op.Cit., hal. 3.

${ }^{16}$ Naskah aslinya menyebutkan : "Een overeenkomst in de zijn van dze titel isn een meerzijdige rechtshandeling, waarbij een of meer partijen jegens een of meer andere een verbintenis aangaan" Lihat R.J. Q Klomp (red), Burgerlijk Wetboek, Boken 1 t/m 8, Ars Aequi Libri, nijmegen, 1997. 
tidak dikenal dengan suatu nama tertentu, tunduk pada peraturan umum yang termuat dalam bab ini dan bab yang lain.

Sambil menunggu Undang-Undang yang secara khusus mengatur ketentuan yang lengkap yang mengatur segala hal tentang perjanjian jual putus, maka berdasarkan Pasal 1319 KUH Perdata tersebut, perjanjian jual putus juga tunduk kepada ketentuan Buku III KUH Perdata yang didalamnya memuat asas-asas perjanjian pada umumnya. Perjanjian Jual Putus tentu saja muncul dibuat karena manusia memiliki asas dalam dirinya untuk secara bebas membuat kontrak sebagaimana diatur dalam pasal 1338 ayat $1 \mathrm{KUH}$ Perdata. Karena dalam prakteknya, asas kebebasan berkontrak seperti itu benarbenar telah menjadi dasar bagi bentuk perjanjian jual putus ini, dimana asas ini memberikan hak kepada penjual dan pembeli untuk membuat perjanjian dalam bentuk apapun dengan siapapun, dengan isi perjanjian yang memenuhi ketentuan Pasal 1320 KUH Perdata.

Asas kebebasan berkontrak sendiri sejatinya muncul karena andil para penganjur hukum alam, yang bermula dalam abad ke-17 dan abad ke-18, menyatakan bahwa manusia dituntun oleh suatu asas bahwa ia adalah bagian dari alam dan sebagai makhluk yang rasional dan cerdas ia bertindak sesuai dengan keinginan-keinginananya (desires) dan gerak-gerak hatinya. Manusia adalah agen yang merdeka (free agent) dan oleh karena itu adalah wajar untuk tidak terikat yang sama wajarnya dengan terikat (that is just as natural to be unbound as it is to be bond). ${ }^{17}$

Filsafat enlightment mengingatkan kita bahwa formalisme (teori formal tentang hukum) dapat menjerumuskan seseorang ke dalam kelemahan yang menganggap semua orang cukup berpendidikan untuk memahami hukum dan cukup rasional untuk menundukkan diri pada hukum. ${ }^{18}$ Disatu sisi ada anggapan bahwa manusia adalah mahluk yang bebas namun disisi lain ada kondisi yang menunjukkan bahwa terdapat pihak-pihak yang lebih kuat menyalahgunakan asas hukum alam di atas untuk memaksakan jaminan kepentingan hak-haknya secara sepihak (one-sided) terhadap pihak yang lemah dan mengecualikan kewajiban-kewajiban hukumnya kepada pihak yang lemah tadi. Sehingga tepatlah apa yang disinyalir oleh Atiyah bahwa Kebebasan berkontrak telah gagal. ${ }^{19}$

Perjanjian Jual putus juga dilahirkan untuk melakukan pengalihan kepemilikan Hak Cipta oleh Pengarang kepada Penerbit, tentu saja masing-masing terikat kepada asas itikad baik. Hal ini disebabkan karena menurut pasal 1338 ayat (3) KUH Perdata, suatu perjanjian haruslah dilaksanakan dengan itikad baik. Pada awalnya itikad baik hanyalah merupakan syarat yang harus dipenuhi dalam pelaksanaan suatu kontrak dan bukan merupakan syarat sah untuk terjadinya kontrak menurut Pasal $1320 \mathrm{KUH}$ Perdata. ${ }^{20}$ Namun demikian berkembangnya pengaruh ajaran itikad baik dikemudian hari meliputi semua tahapan perjanjian, baik pada phase dibuatnya perjanjian (pra contractuele fase), pada pelaksanaan perjanjian dan pada phase setelah perjanjian. Hal ini telah memberikan pengaruh besar untuk menahan dominasi pihak yang kuat terhadap pihak yang lemah menuju kewajaran, kepatutan dan keadilan dalam perjanjian. Tepatlah kiranya dalam konteks ini sebagaimana disebutkan oleh Pasal 1339 KUH Perdata yang menegaskan bahwa: Perjanjian tidak saja mengikat untuk hal-hal yang dengan tegas dinyatakan di

${ }^{17}$ Sutan Remy Sjahdeini, Kebebasan berkontrak dan Perlindungan yang Seimbang bagi Para Pihak dalam Perjanjian Kredit Bank di Indonesia, Jakarta, IBI, 1993, hlm.19.

${ }^{18}$ Nasikun, "Hukum dalam Paradigma Sosial”, dalam Artidjo Alkostar (ed), Identitas Hukum Naisonal, Yogyakarta, Fakultas Hukum UII, 1997, hlm. 160-161. hlm. 31

${ }^{19}$ Demikian pendapat P.S. Atiyah sebagaimana tersebut dalam Sutan Remy Sjahdeini, Op. Cit.,

${ }^{20}$ Pandangan ini persis sama dengan yang terkandung dalam Restatement Second, Section 25. Dalam penjelasan nya dikatakan : "every contract imposes upon each party a duty of good faith and fair dealing in its performance and enforcement". Sebagaimana dijelaskan oleh Ridwan Khaerandy dalam "Kemerosotan supremasi kebebasan berkontrak", makalah, tanpa tahun. 
dalamnya, tetapi juga untuk segala sesuatu yang menurut sifat perjanjian diharuskan oleh kepatutan, kebiasaan atau undang-undang.

Ketentuan Bagian Ketiga BAB Kedua Buku III KUH perdata, khususnya Pasal 1338 KUH Perdata Jo. Pasal 1339 KUH Perdata sejatinya dapat membingkai praktek pembuatan Perjanjian Jual Putus. Pembuatan Perjanjian Jual Putus dalam praktek agar mengindahkan asas-asas yang dikenal dalam KUH Perdata, aturan-aturan baik yang secara tegas diatur dalam KUH Perdata, juga harus mengingat kepatutan, kebiasaan dan undang-undang serta timbul karena terjadinya kesepakatan, yang dikehendakai oleh para pihak tersebut diperoleh oleh mereka yang tidak dalam keadaan cacat untuk berkehendak, yang meliputi keadaan seperti:

a) Adanya kesesatan atau kekeliruan

b) Adanya paksaan

c) Adanya penipuan

d) Dalam perkembangan lebih lanjut, dikenal pula cacat kehendak lain, yakni penyalahgunaan keadaan (misbruike van omstandigheiden). ${ }^{21}$ Atau Pengaruh tak pantas (Undue Influence) ${ }^{22}$

e) Kontrak tersamar (Implied Contract)

Dalam ketentuan Pasal 1601 KUH Perdata tersebut sebetulnya mengandung pesan, bahwa terhadap perjanjian Jual Putus haruslah dibuatkan ketentuan-ketentuan khusus untuk itu, oleh syarat-syarat yang harus diperjanjian dan jika tidak ada dapat menggunakan sumber kebiasaan. Dengan demikian untuk sementara dapat diperoleh kesimpulan bahwa dalam pembuatan perjanjian Jual Putus yang merupakan suatu bentuk perjanjian jenis baru yang pelaksanaannya dapat tunduk pada aturan: (1) Buku III KUH Perdata, yang juga memuat ketentuan tentang Perjanjian Jual Beli yang dalam banyak hal dapat dijadikan sandaran awal untuk pembuatan Perjanjian Jual Putus Hak Cipta, (2) ketentuan-ketentuan yang khusus yang harus dibuat untuk itu seperti misalnya perjanjian waralaba (3) oleh syarat-syarat yang timbul dari perjanjian dan (4) kebiasaan.

Selanjutnya pembahasan terhadap Perjanjian Jual Putus yang merupakan kontrak yang prestasinya berobyek kebendaan, khususnya kebendaan yang tidak berwujud, maka selain menggunakan asas-asas yang tunduk kepada Buku ke 2 tentunya juga telah diberikan aturan yang dibahas secara rinci dalam pasal-pasal dalam Buku III KUH Perdata. Selain itu karena Hukum Hak Cipta adalah lahir di negara-negara yang menginduk kepada sistem hukum Common Law atau Civil Law, maka menjadi kewajaran pembuatan Perjanjian Jual Putus Hak Cipta dalam banyak hal harus mengambil konsepkonsep, asas-asas dan kebiasaan dalam Kontrak Hak Cipta di negara-negara tersebut, khususnya Belanda dan Amerika Serikat.

Prinsip-prinsip khas Hukum Hak Cipta yang tumbuh dalam sistem Civil Law menjadi hukum yang mempengaruhi pertumbuhan Hukum Hak Cipta setelah merdeka, yaitu Undang-Undang Nomor 6 Tahun 1982 Tentang Hak Cipta. Tindakan Pemerintah Kolonial Belanda yang memberlakukan Auteurswet 1912 Stb. Nomor 600 di daerah jajahannya kemudian diteruskan tindakan pemerintah Indonesia mentranspalansikan Auteurswet 1912 Stb. Nomor 600 kedalam Undang-Undang Nomor 6 Tahun 1982 Tentang Hak Cipta adalah kebijakan yang bertentangan dengan dasar-dasar kultural. Di sinilah

${ }^{21}$ Cacat kehendak di atas menurut J. Satrio, Perikatan yang Lahir dari perjanjian, Buku I Citra Aditya Bakti, Bandung, 1995, hlm. 164. lihat juga Mariam Darus Badrulzaman, Aneka Hukum Bisnis, Alumni, Bandung, 1994, hlm. 24.

${ }^{22}$ Doktrin pengaruh tak pantas (undue Influence) adalah suatu doktrin yang mengajarkan bahwa suatu kontrak dapat dibatalkan karena tidak tercapai kesesuaian kehendak disebabkan oleh adanya usaha oleh salah satu pihak, karena kedudukan khususnya (seperti kedudukannya yang lebih dominan, adanya hubungan yang rahasia atau hubungan fiduciary). Lihat dalam Munir Fuady. Op.Cit., hlm.58. 
sebetulnya Indonesia harus melihat dalam kenyataan bahwa konsep rule of law tidaklah selamanya tepat jika dipahami dari aspek law-nya saja tetapi haruslah dipahami dari aspek manusia (man) dengan segala lingkaran kultural yang megitarinya. Sebab negara ini didirikan tidak semata-mata untuk menegakkan rule of law melainkan juga rule of man. ${ }^{23}$

Sebagai contoh, tindakan seorang pembatik di Solo yang meniru motif batik Danar Hadi dan beredar di pasar Klewer Solo tanpa menyebut nama pencipta, oleh Pak Santoso Almarhum pemilik Batik Danar Hadi, ${ }^{24}$ didiamkan saja dengan alasan biarkan masyarakat meniru dan hidup sekedar mencari kebutuhan ekonominya. Jawaban Pemilik Hak Cipta tersebut adalah sangat bertentangan dengan Hak Cipta adalah Hak Tunggal pada prinsip Auteurswet 1912 Stb. Nomor 600, akan tetapi menjadi kultur masayarakat Indonesia asli yang memperbolehkan. Ini bukan persoalan benar atau salah, boleh jadi apa yang menjadi respon pendiri dan pemilik Batik Danar Hadi tersebut dapat dikoreksi dengan memberikan bingkai bahwa sebetulnya Hak Ekonomi dan Hak Moral itu dapat diperalihkan kepada orang lain asalkan Pemilik Hak Cipta memperbolehkan dalam perjanjian lisan sekalipun. Konsep Peralihan Hak Cipta seperti ini dikenal di Sistem Civil Law untuk Hak Ekonomi dan dalam Sistem Common Law untuk Hak Ekonomi beserta Hak Moralnya sekaligus asalkan disepakati oleh Pencipta. Bahkan terhadap Hak Moral yang pada prinsipnya dilarang dialihkan oleh UU Hak Cipta di negara penganut sistem Civil Law, namun jika sudah dilakukan perjanjian peralihan kepada Penerbit, maka Perjanjian itulah yang belaku mengikat. .

Indonesia secara tradisi tunduk pada monisme theory yang berlaku dalam sistem Civil Law, dimana sangat terkait dengan konsep G.W. Frederich Hegel dengan Personality theory yang sangat sentral terhadap kepribadian Pencipta, sehingga Hak Ekonomi dan Hak Moral tidak dapat dipisahkan. Dalam Negara Common Law menganut dualisme theory, yang memisahkan antara Hak Ekonomi dengan Hak Moral. Hak Moral hanya melindungi manuskrip dan menjadi tugas Common Law untuk melindungi, sedangkan Hak Ekonomi atas Ciptaan dilindungi oleh Undang-Undang Hak Cipta dan dengan perjanjian dapat dilakukan peralihan yang mengalihkan hak pencipta sama sekali.

Dalam praktek Perjanjian Jual Putus yang bertujuan mengalihkan Hak Ekonomi dari Pengarang kepada Penerbit memang sungguh-sungguh terjadi sebagaimana dieksternalisasikan oleh pembentuk UUHC dalam Penjelasan Pasal 18 UUH dan Pasal 122 UUHC. Melihat model Perjanjian Jual Putus dalam praktek, maka secara kasat mata menegaskan hak-hak Pencipta tidak mendapatkan perlindungan dan Pencipta tidak memiliki kuasa untuk memperjuangkan hak-hak sebagai penjual dalam setiap tahapan perjanjian, baik pra kontrak maupun pelaksanaan kontrak, terlebih jika ada konflik. Terlihat dengan jelas, bahwa Perjanjian Jual Putus tidak dibangun berdasarkan asas-asas hukum, ketentuan-ketentuan hukum yang dibuat khusus oleh negara, tidak berdasarkan kebiasan-kebiasan yang berlaku dalam pergaulan hukum Hak Cipta dalam sistem hukum Civil Law maupun Common Law.

Tabel 4.1

\begin{tabular}{|c|c|c|c|}
\hline \multicolumn{4}{|c|}{$\begin{array}{l}\text { STUDI PERBANDINGAN HUKUM PERALIHAN KEPEMILIKAN HAK CIPTA BUKU } \\
\text { MELALUI PERJANJIAN JUAL PUTUS }\end{array}$} \\
\hline SUBSTANSI & BELANDA & AMERIKA & INDONESIA \\
\hline Sistem Hukum & Civil Law & Common Law & $\begin{array}{l}\text { Civil Law dan Common } \\
\text { Law }\end{array}$ \\
\hline Dasar Filosofis & $\begin{array}{l}\text { G.W.Frederich } \\
\text { Hegel }\end{array}$ & John Locke & G.W.Frederich Hegel \\
\hline
\end{tabular}

${ }^{23}$ lihat dalam OK. Saidin, Op.Cit., hlm 93.

${ }^{24}$ Wawancara Penulis saat menjadi peserta kunjungan ke Danar Hadi sekitar tahun 2002. 


\begin{tabular}{|c|c|c|c|}
\hline $\begin{array}{l}\text { Teori } \\
\text { Kepemilikan }\end{array}$ & Personality theory & Labour theory & Personality theory \\
\hline $\begin{array}{l}\text { Tolok ukur } \\
\text { perlindungan }\end{array}$ & Pencipta (Author) & Ciptaan(creation/copyrighted works) & Pencipta (Author) \\
\hline $\begin{array}{l}\text { Persyaratan } \\
\text { Ciptaan }\end{array}$ & $\begin{array}{ll}\text { 1. } & \text { Ketrampilan } \\
\text { (Skill) } \\
\text { 2. Usaha (labour) } \\
\text { 3. Wujud nyata } \\
\text { kreatifitas } \\
\text { kepribadian } \\
\text { pencipta }\end{array}$ & $\begin{array}{ll}\text { 1. } & \text { Ketrampilan (Skill) } \\
\text { 2. } & \text { Usaha (labour) }\end{array}$ & $\begin{array}{ll}\text { 1. } & \text { Ketrampilan (Skill) } \\
\text { 2. Usaha (labour) } \\
\text { 3. Wujud nyata } \\
\text { kreatifitas } \\
\text { kepribadian } \\
\text { pencipta }\end{array}$ \\
\hline Wujud Ciptaan & $\begin{array}{ll}\text { Sebagai } & \text { benda } \\
\text { Immateriil } & \\
\end{array}$ & Sebagai benda Immateriil & $\begin{array}{ll}\text { Sebagai } & \text { benda } \\
\text { Immateriil } & \\
\end{array}$ \\
\hline $\begin{array}{l}\text { Perlakuan dan } \\
\text { Perlindungan } \\
\text { terhadap } \\
\text { manuskrip }\end{array}$ & $\begin{array}{l}\text { Harus diatur dalam } \\
\text { UU }\end{array}$ & $\begin{array}{l}\text { Manuskrip dilindungi Common } \\
\text { Law } \\
\text { Buku Cetakan dilindungi UU }\end{array}$ & Harus diatur dalam UU \\
\hline $\begin{array}{l}\text { Teori } \\
\text { Perlindungan } \\
\text { Hak Cipta }\end{array}$ & Monistik & Dualistik & $\begin{array}{l}\text { Monistik menuju } \\
\text { Campuran }\end{array}$ \\
\hline $\begin{array}{l}\text { Peralihan } \\
\text { kepemilikan Hak } \\
\text { Cipta }\end{array}$ & $\begin{array}{l}\text { Hak Ekonomi } \\
\text { Hak Moral dilarang }\end{array}$ & $\begin{array}{l}\text { Hak Ekonomi } \\
\text { (Tidak ada Hak moral) }\end{array}$ & $\begin{array}{l}\text { Hak Ekonomi } \\
\text { Hak Moral dilarang }\end{array}$ \\
\hline $\begin{array}{l}\text { Istilah Transfer } \\
\text { Hak Cipta }\end{array}$ & $\begin{array}{l}\text { Overdracht } \\
\text { licency }\end{array}$ & $\begin{array}{l}\text { Assignment } \\
\text { Waiver } \\
\text { Licency }\end{array}$ & $\begin{array}{l}\text { Lisensi } \\
\text { Jual Putus }\end{array}$ \\
\hline $\begin{array}{l}\text { Dasar Hukum } \\
\text { Peralihan } \\
\text { Kepemilikan } \\
\end{array}$ & $\begin{array}{l}\text { UU } \\
\text { Dan perjanjian } \\
\text { Tertulis }\end{array}$ & Perjanjian dan Yurisprudensi & $\begin{array}{l}\text { Pasal } 18 \text { UUHC } \\
\text { Dan tidak ada peraturan } \\
\text { pelaksananya }\end{array}$ \\
\hline
\end{tabular}

Sumber: data sekunder, 2021.

\section{Pengaturan Perjanjian Jual Putus dalam KUH Perdata}

\section{a. Perjanjian Jual Putus sebagai Perjanjian Jenis Baru}

Salah satu cara yang disediakan dalam UUHC untuk mengakomodir hubungan Pencipta dengan penerbit atau produser adalah dituangkannya dalam perjanjian jual putus hak cipta. Mencari istilah perjanjian jual putus dalam Buku III KUH Perdata tentu saja tidak dapat menemukannya. Dapat dikatakan bahwa perjanjian jual putus adalah bukan perjanjian yang namanya dicantumkan dalam Buku III KUH Perdata, sehingga tidak masuk dalam istilah perjanjian bernama. Perjanjian yang diatur secara khusus dalam Buku III KUH Perdata disebut perjanjian bernama (nominat) sedangkan perjanjian yang tidak diatur dalam Buku III KUH Perdata disebut perjanjian tidak bernama (innominat) atau perjanjian jenis baru.

Makna perjanjian bernama adalah perjanjian yang namanya secara khusus dicantumkan dan diatur dalam Buku III KUH Perdata. Pasal 1319 KUH Perdata memberikan ketentuan munculnya perjanjian jenis baru, yaitu persetujuan yang tidak terkenal dengan suatu nama tertentu. Pasal 1319 KUH Perdata secara lengkap berbunyi: Semua perjanjian, baik yang mempunyai nama khusus maupun yang tidak dikenal dengan suatu nama tertentu, tunduk pada peraturan umum yang termuat dalam bab ini dan bab yang lain.

Istilah perjanjian jual putus atau kemudian istilah bahasa Inggrisnya sold flat pertama kali ditemukan dalam Pasal 18 UUHC dan Penjelasan Pasal 18 UUHC, yang secara lengkap menegaskan bahwa Pasal 18 UUHC: Ciptaan buku, dan/atau semua hasil karya tulis lainnya, lagu dan/atau musik dengan atau tanpa teks yang dialihkan dalam perjanjian jual putus dan/atau pengalihan tanpa batas waktu, Hak Ciptanya beralih kembali kepada Pencipta pada saat perjanjian tersebut mencapai jangka waktu 25 (dua puluh lima) tahun. 
Sedangkan Penjelasan Pasal 18 UUHC: Yang dimaksud dengan "jual putus" adalah perjanjian yang mengharuskan Pencipta menyerahkan Ciptaannya melalui pembayaran lunas oleh pihak pembeli sehingga hak ekonomi atas Ciptaan tersebut beralih seluruhnya kepada pembeli tanpa batas waktu, atau dalam praktik dikenal dengan istilah sold flat.

Dalam membahas lebih lanjut definisi dalam Pasal 18 UUHC dimana dimunculkan konsep hukum yang mengandung anasir kata jual dan ada frasa pembayaran lunas oleh pembeli, dan UUHC tidak memberikan secara rinci apa yang dikehendaki oleh pembentuknya. Penjelasan Pasal 18 UUHC, hanya memberikan istilah sold flat sebagai nama perjanjian dalam praktek. Mengenai sold flat, adalah perjanjian yang tidak diatur secara khusus dalam KUHPerdata, kita tidak bisa menjumpai istilah itu dalam Buku III KUH Perdata, namun demikian Buku III KUH Perdata tersebut menganut sistem terbuka. Dalam sistem terbuka itulah maka para pihak boleh membuat perjanjian yang tidak diatur secara khusus dalam KUHPerdata.

Menjadi suatu persoalan dalam istilah sold flat yang ada dalam Pasal 18 UUHC tersebut dikarenakan adanya kata jual dan pembayaran lunas oleh pembeli yang itu merupakan unsur khas dalam perjanjian jual beli, sehingga sebetulnya ketentuan-ketentuan dalam KUH Perdata yang dapat di pergunakan adalah peraturan tentang jual putus. Jika kita mencermati Pasal 18 dan ketentuan Penjelasan Pasal 18 UUHC, hakekatnya g menegaskan bahwa perjanjian itu dibuat oleh masyarakat untuk mengalihkan kepemilikan Hak Cipta, otomatis juga tentunya mengalihkan hak eksklusif pencipta yang memungkinkan mereka mendapatkan nilai ekonomi dari ciptaan secara penuh kepada pembeli Hak Cipta, yang secara timbak balik telah membayar lunas. Pemenuhan kewajiban Pembeli Hak Cipta dengan cara pembayaran lunas tersebut, memberikan konsekuensi hak ekonomi atas Ciptaan tersebut beralih seluruhnya kepada pembeli tanpa batas waktu. Akibat selanjutnya yang terjadi adalah seharusnya juga mengalihkan pemberian jangka waktu perlindungan selama hidupnya ditambah 70 tahun, walaupun tetap memberikan hak moral kepada pencipta yang berlaku tanpa batas waktu.

Selain hakekat tujuan dari pengaturan Pasal 18 diatas, maka UUHC memberikan penekanan lanjutan dengan ketentuan Pasal 122 UUHC, yang memberikan perlindungan kepada penjual selaku pemilik hak moral yang dialihkan hak ekonominya secara keseluruhan tanpa batas waktu melalui jual putus. Perjanjian Jual Putus yang mengalihkan Hak Ekonomi secara keseluruhan dan tanpa batas waktu ini memberikan kewajiban kepada Pencipta atau pemegang Hak Cipta untuk tidak mengalihkan untuk kedua kalinya, sebagai mana diatur dalam Pasal 17 ayat (2) UUHC.

Walaupun Perjanjian jual putus ini bukan satu satunya obat mujarab bagi jalan keluar atas situasi ekonomi yang merepotkan investasi pihak pembeli, namun situasi akan lebih buruk yang dapat terjadi terhadap maksud dan tujuan UUHC apabila dalam perjanjian jual beli tersebut tidak memuat klausula yang dapat merugikan kepentingan pencipta. Idealnya, perjanjian jual putus yang ditandatangani antara pencipta selaku penjual dan investor selaku pembeli ciptaan harus memberikan perlindungan yang seimbang dalam kepentingan ekonomi, bagi para penulis dan karya mereka.

Belajar dari kasus yang terjadi di Amerika Serikat, menjadi penting bahwa ketentuan Pasal 18 UUHC dimasukkan dalam Undang-Undang. Dalam kasus di Amerika, UU Hak Cipta dapat mengalahkan kedudukan perjanjian yang walaupun menjadi hukum namun sifatnya hanya memberi perlindungan kepada kedua belah pihak, sedangkan Undang-Undang adalah menjadi hukum yang melindungi masyarakat dimana UndangUndang tersebut berlaku. Oleh karena itu negara-negara harus memasukkan kedalam undang-undang nasionalnya untuk menyepakati model perjanjian Jual Putus, bagiamanapun ketentuan UUHC memberikan perlindungan yang lebih kuat karena berlaku kepada banyak orang di seluruh dunia dari pada sebuah kontrak. 
Di Indonesia, ketentuan tentang jual beli telah ada terlebih dahulu dari pada jual putus sebagaimana diatur mulai dari Pasal 1457 KUH Perdata, "Jual beli adalah persetujuan atau perjanjian yang mengikat penjual dan pembeli, penjual mengikatkan diri untuk menyerahkan suatu barang yang disetujuai bersama, dan pembeli mengikatkan diri untuk membayar harga barang, yang disetujui bersama."

Karena Perjanjian Jual Beli diatur dalam KUH Perdata, maka disebut perjanjian nominaat atau perjanjian bernama, yaitu perjanjian yang nama-namnya sudah diatur dalam KUH.Perdata. Perjanjian Jual Beli sebagaimana diatur dalam Pasal 1457 KUH Perdata adalah perjanjian tidak bersyarat. Perjanjian yang tidak memiliki syarat apapun, karena terjadi begitu bertemunya sejak awal penawaran dan penerimaan dari para pihak. Hal ini berbeda dengan Pasal 18 UUHC, dimana pada awalnya sebagai perjanjian jual putus, akan tetapi setelah 25 tahun memiliki syarat harus dikembalikan hak ekonominya kepada Pencipta. Sehingga sebetulnya sampai disini saja Pasal 18 UUHC tidak dapat disejajarkan atau disamakan dengn Jual beli berdasarkan Pasal 1457 KUH Perdata. Pasal 18 UUHC adalah perjanjian yang diatur dalam KUH Perdata, maka disebut perjanjian innominaat atau perjanjian tak bernama atau perjanjian jenis baru.

Perbandingan dari isi ketentuan Pasal 18 UUHC dengan Pasal 1457 KUH Perdata menunjukkan bahwa sebetulnya apa yang diatur dalam Pasal 1457 KUH Perdata sudah termaktub di dalam ketentuan Pasal 18 UUHC, namun demikian tetaplah ada perbedaan prinsipil antara kedua ketentuan tersebut, maka dapatlah dikatakan Pasal 18 UUHC adalah model perjanjian baru, yang jenis dan namanya tidak ada dalam KUH.Perdata.

Ketentuan pasal 1457 KUH Perdata memberikan unsur-unsur yang terkandung dalam jual beli, yaitu sebagai berikut: Adanya para pihak; Adanya barang yang ditransaksikan; Ada harga; dan Ada pembayaran dalam bentuk uang.

Sedangkan dari ketentuan Pasal 18 UUHC dimana mengatur selain unsur-unsur dalam ketentuan jual beli berdasarkan Pasal 1457 KUH Perdata di atas, juga memiliki unsur tambahan yaitu: Adanya pelunasan uang; Adanya penyerahan; Ada peralihan kepemilikan tanpa batas waktu; Ada syarat batasan waktu

Dari kedelapan unsur yang dibawa oleh Pasal 18 UUHC dalam sistem hukum perdata yang berlaku di Indonesia akan berdampak luar bisa terhadap konsep jual beli menurut Pasal 1457 KUH Perdata. Setidaknya ada lima hal dari unsur-unsur perjanjian jual putus yang akan menjadi permasalahan terkait konsepsi, asas dan aturan yang meliputi unsur sebagai berikut:

1) adanya barang yang ditransaksikan,

2) unsur pelunasan uang,

3) unsur penyerahan,

4) unsur peralihan kepemilikan, dan

5) unsur adanya syarat pembatasan waktu.

\section{b. Perjanjian Jual Putus sebagai Perjanjian Kebendaan}

Perjanjian Jual Putus mensyaratkan adanya barang yang dipindahkan, sehingga Perjanjian Jual Putus dalam Pasal 18 UUHC adalah perjanjian Kebendaan. Berkaitan dengan hal tersebut di atas, maka bangunan konsep peralihan hak cipta melalui perjanjian jual putus secara tertulis dalam UUHC dengan obyek perjanjian adalah hak cipta sebagai hak milik perseorangan yang bersifat immateriil dan memiliki hak kebendaan, sehingga juga disebut perjanjian kebendaan dimana dalam hak kebendaan atas suatu ciptaan tersebut melekat hak yang bersifat ekslusif yang diberikan oleh negara berdasarkan undang-undang.

Dalam sistem tertutup yang khas dalam hukum benda, keberadaan hak kebendaan adalah mutlak dan terdapat larangan untuk mengadakan hak kebendaan baru, namun dalam pengertian tersebut tidak disebut tentang larangan menghilangkan hak kebendaan. Penghilangan hak-hak kebendaan dapat dilakukan dengan menggunakan Hukum Perutangan yang khas menganut sistem terbuka. Dalam hukum perutangan yang bersifat 
terbuka memberikan halk pada setiap orang untuk dapat mengadakan atau tidak mengadakan verbintenis atau perjanjian mengenai apapun juga, baik yang sudah ada aturannya dalam undang-undang (yaitu dalam KUH Perdata, KUHD, Peraturan khusus) maupun yang belum ada peraturannya sama sekali.

Selain bersifat tertutup, dalam hukum benda berlaku azas umum yaitu sebagai hukum pemaksa artinya berlakunya aturan-aturan itu tidak dapat disimpangi oleh para pihak. Sebagaimana telah kita ketahui, atas sesuatu benda itu hanya dapat diadakan hak kebendaan sebagaimana yeng telah ditentukan dalam undang-undang.

Di sisi lain ada asas umum yang lain dalam hukum benda yaitu dapat dipindahkan, kecuali isinya oleh undang undang juga ditentukan sifat-sifatnya hak kebendaan. Kecuali hak pakai dan mendiami semua hak kebendaan dapat dipindah-tangankan. Ketentuan ini memberikan ketegasan bahwa kepada yang berhak saja tidak dapat menentukan bahwa benda ini tidak dapat dipindah-tangankan. Larangan pemindah tanganan suatu benda hanya dapat dilakukan jika memenuhi ketentuan Pasal 1337 KUH Perdata, yaitu suatu sebab adalah terlarang, apabila dilarang oleh undang-undang, atau apabila berlawanan dengan kesusilaan baik atau ketertiban umum. Khususnya "etische causaliteitsregel" yakni tidak berlaku jika tujuannya bertentangan dengan kesusilaan.

Sebagai hak kebendaan, Hak cipta tentunya juga memberikan hak kepada pemiliknya untuk dapat memindah-tangankan. Konsep peralihan Hak Cipta yang yang berlaku di Indonesia adalah mengacu kepada hukum Hak Cipta Negeri Belanda. Dimana di negeri Belanda sangat menjunjung tinggi asas droit de suite dalam melindungi hak moral sebagai hak kebendaan yang mengikuti pemiliknya (pencipta).

Dalam praktek, sesungguhnya tidak ada yang dapat melarang seandainya pemilik hak moral berkehendak untuk mengalihkannya melalui perjanjian jual putus. Walaupun dalam Pasal 18 UUHC hanya menyebut secara tegas peralihan hak ekonomi, sedangkan konsep perlindungan hak ekonomi sendiri adalah merupakan sumber dari hak untuk memperbanyak (right to copy) dan ini merupakan warisan dari negara dengan sistem Common Law (Anglo Saxon), maka mengalihkan hak moral pun dilakukan dalam motif mendapatkan keuntungan ekonomi. Dalam praktek, Penerbit seringkali menerima naskah dari pengarang dan pengarang berkeinginan untuk mengalihkan Hak Ekonomi dan Hak Moral sekaligus. Penerbit menolak peralihan hak moral berdasarkan alasan bukan karena Hak Moral dilindungi oleh undang-undang dan tidak boleh dialihkan, sebagai alasan untuk menolak permintaan pengarang. Alasan penerbit menolak peralihan hak moral lebih karena alasan teknis, terkait pertanggungjawaban penerbit atas buku, jika mengandung hal-hal yang bertentangan dengan SARA.

Namun jelas bahwa pengalihan Hak Moral tetaplah ada dalam praktek, tetapi Penerbit Media Pressindo Yogyakarta tidak memiliki perjanjian pengalihan hak moral karena selama ini hanya pengalihan hak ekonomi, dari yang sebagian sampai yang keseluruhan, sebagaimana diatur dalam Pasal 9 UUHC. ${ }^{25}$ Lebih Lanjut Indra Ismawan menyampaikan bahwa, penulis hantu (ghostwriter) tetap lah ada dan mereka menulis untuk menjual baik hak ekonomi atau hak moralnya dengan mendapatkan penggantian atas peralihan Hak Cipta bervariasi dan berkisar antara Rp. 3.000.000,- sampai dengan Rp. 5.000.000,-. Ismantoro Dwi Yuwono, bahkan menyebutkan ada penerbit yang hanya memberikan harga peralihan beli putus Hak Moral sebesar Rp. 500.000,- ${ }^{26}$. Dalam prakteknya, buat penulis pemula, harganya sama sekali tidak fantastis, kisarannya di bawah

${ }^{25}$ Wawancara dengan Indra Ismawan, Penerbit Media Pressindo beralamat di Jl. Cempaka Putih CT. X No. 8, Catur Tunggal,. Depok, Sleman, tanggal 7 November 2020

26 sumber facebook Ismantoro Dwi Yowono, 24 Oktober 2020, https://www.facebook.com/ismantoro.dwiyuwono/posts/3746254228732583 
Rp 5.000.000,- per naskah. Jarang-jarang ada penerbit yang mau membayar penulis pemula, sebagus apapun naskahnya dengan harga di atas Rp 10.000.000,-/ naskah. ${ }^{27}$

Tetapi, jika tidak dilakukan Perjanjian Jual Putus dengan penerbit, maka akan mendapatkan peluang untuk mendapatkan harga yang lebih baik. Hal ini disampaikan Dodi Mawardi, Pendiri Sekolah Menulis Kreatif Indonesia yang menyatakan bahwa: ${ }^{28}$

Bagi penulis produktif dan sudah punya nama, baik royalti maupun jual putus, sama-sama menariknya. Perlu strategi jitu untuk memilihnya, sesuai dengan momentum dan kebutuhan. Saya misalnya menerapkan strategi jual putus bukan ke penerbit, karena tahu persis jarang penerbit mau keluar uang banyak, tapi kepada pihak lain yang mau menggunakan jasa penulisan. Dia yang punya ide dan bahan, lalu saya yang menuliskannya (pilihan jasa ghost atau co-writer). Biasanya mereka adalah pengusaha, pembicara terkenal, atau pejabat dan mantan pejabat. Mereka bersedia investasi dana cukup besar, untuk penulisan buku. Tentu cukup menarik bukan kalau menulis sebuah buku dan dibayar Rp 50.000.000,-/naskah? Banyak penulis yang dibayar sampai Rp 100.000.000,-/naskah atau bahkan lebih.

\section{c. Perjanjian Jual Putus sebagai Perjanjian Obligatoir}

Di dalam hukum Belanda, perjanjian jual beli murni bersifat konsensual. Konsensus yang sebetulnya dilandasi motif untuk saling berhadap-hadapan dimana pihak penjual berkeinginan untuk segera menjual bendanya dengan harga setinggi-tingginya, melalui penawaran dan sebaliknya ada keinginan pembeli untuk menerima penawaran itu dengan segera mendapatkan bendanya dengan harga termurah. Dasar utama adalah yang berkaitan dengan penyerahan benda dan untuk membayar harga adalah kesepakatan antar penjual dan pembeli. Pasal 1457 KUH Perdata mengandung makna bahwa perjanjian jual beli terjadi setelah para pihak mencapai kesepakatan (overeenkomst) mengenai barang dan harganya. Lebih lanjut dinyatakan oleh Pasal 1458 KUH Perdata bahwa kesepakatan atas jual beli itu telah terjadi meskipun barang tersebut belum di bayar lunas dan barangnya belum diserahkan.

Peralihan kepemilikan barang tidak terjadi pada saat adanya kesepakatan tentang benda dan harganya, melainkan baru beralih kepemilikan kepada pembeli setelah penjual menyerahkan (levering) kepada pembeli dan pembeli melunasi harganya (Pasal 1459 KUH Perdata). Sedangkan Pasal 18 UUHC, jika kita pahami adalah mencampurkan ketiga pasal tersebut yaitu Pasal 1457, Pasal 1458 dan pasal 1459 KUH Perdata. Perjanjian jual beli bersifat "obligatoir" dalam arti bahwa ia belum memindahkan hak milik. Sebab, yang memindahkan hak milik adalah perbuatan hukum tersendiri yang disebut dengan "levering". Perbuatan hukum levering dikontruksikan sebagai suatu "qakelijke overeenskomst" yaitu suatu perbuatan timbal balik yang berintikan pemindahan hak kepemilikan [transfer of ownership].

Perjanjian Jual Putus dalam Pasal 18 UUHC juga sejatinya merupakan perbuatan timbal balik dalam peralihan hak kepemilikan dalam Hak Cipta. Mengacu pada bangunan konsep jual beli dalam sistem hukum Civil Law yang menggunakan model pendekatan melalui hukum di Perancis sebagai penganut sistem code civil, menyebutkan bahwa hak milik berpindah pada saat perjanjian jual beli ditutup yang serta merta telah terjadi "levering" hak milik kepada pembeli [feitelijke levering]. Sedangkan dalam sistem Common Law, misalnya di Inggris, perjanjian jual beli dibedakan dalam "sale contract" [actual sale] dan "agreement to sale'. Sale Contract adalah perjanjian jual beli yang sekaligus memindahkan hak milik, sedangkan agreement to sale seperti koopovereenskomst atau janji menjual yang belum mengakibatkan pindahnya hak milik.

Salah satu cara peralihan hak milik adalah melalui penyerahan atas dasar peristiwa perdata atau alas hak (titel) yang dilakukan oleh orang yang berwenang. Hal ini sejalan

\footnotetext{
${ }^{27}$ https://dodimawardi.wordpress.com/2015/03/31/pilih-royalti-atau-jual-putus/

${ }^{28}$ Ibid.
} 
dengan Pasal 584 KUH Perdata, yaitu :"Hak milik atas sesuatu kebendaan tak dapat diperoleh dengan cara lain, melainkan dengan pemilikan, karena perlekatan, karena daluwarsa, karena pewarisan, baik menurut undang-undang, maupun menurut surat wasiat, dan karena penunjukan atau penyerahan berdasar atas suatu peristiwa perdata untuk memindahkan hak milik, dilakukan oleh seorang yang berhak berbuat bebas terhadap kebendaan itu".

Berbeda dengan itu, konsep Pasal 18 UUHC sejatinya tidak memiliki tujuan itu, walaupun pada prinsipnya menganut konsep terjadi peralihan dan pembebasan hak kebendaan, walaupun hanya selama masa 25 tahun, tetapi begitu melewati masa 25 tahun mewajibkan dilakukannya pengembalian hak kepada penjual putus. Kalau ini terus dianut, maka problem yang akan terjadi adalah bagaimana jika Penerbit tidak segera melakukan penerbitan atas naskah asli dalam bentuk buku setelah melalui mekanisme penyerahan hak kepemilikan sampai dengan perjanjian memasuki tahun ke 25? UUHC tidak memberikan pengaturan lebih lanjut dan lebih rinci.

Sampai di sini, Pasal 18 UUHC minus anak kalimat terakhirnya, adalah merupakan perjanjian jual putus tanpa batas waktu jika dilihat dari penjelasan pasalnya. Model peralihan hak cipta seperti ini adalah model yang mengikuti negara dengan sistem Common Law dengan assignment of copyright and waiver of moral right in artwork. Tetapi apabila dilihat secara utuh konsep Pasal 18 UUHC ini akan memiliki implikasi hukumnya berbeda. Sejatinya Pasal 18 UUHC, telah mengalihkan kepemilikan yang sudah diserahkan tersebut.

Ketentuan yang ada dalam Pasal 18 UUHC benar-benar bertentangan dengan aturan hukum benda. Didalam aturan hukum benda, terdapat ketentuan yang absolut terkait kedudukan kepemilikan hak cipta yang disertai dengan hak kebendaan, dimana pemiliknya bebas untuk mengalihkan dan/atau tidak mengalihkan bendanya dan tidak boleh ada larangan yang dibuat oleh siapapun untuk menghalanginya.

\section{Rekonseptualisasi Perjanjian Jual Putus dengan Klausula Non Use.}

Perjanjian Jual Putus tunduk pada ketentuan Pasal 18 dan Penjelasan Pasal 18 UUHC, yang merupakan ketentuan satu-satunya yang menyebut Perjanjian Jual Putus dan juga tunduk pada ketentuan-ketentuan UUHC lainnya. Disamping hal tersebut, juga tunduk pada Ketentuan Hukum Benda dalam Buku ke II KUH Perdata dan juga ketentuan Hukum Perjanjian dalam Buku Ketiga sebagai aturan umum yang harus dihormati dan selalu dipakai dalam pembuatan Perjanjian Jual Putus. Sambil menunggu Peraturan Perundang-Undangan khusus yang mengatur Kontrak Hak Cipta, maka Ketentuan dalam KUH Perdata pada prinsipnya tetap berlaku dalam pembuatan Perjanjian Jual Putus, walaupun dalam prakteknya kepentingan Pengarang banyak diabaikan oleh Pihak Penerbit. Belajar dari Undang-Undang Kontrak Hak Cipta (Wet auteurscontractenrecht) yang mulai berlaku 1 Juli 2015, yang memiliki aturan standar yang lebih ketat dalam memebrikan perlindungan bagi kepentingan Pengarang yang melakukan Perjanjian Jual Putus Hak Cipta.

Pada dasarnya, perjanjian ialah suatu peristiwa dimana seseorang berjanji kepada orang lain atau dimana dua orang itu saling berjanji untuk melaksanakan suatu hal. ${ }^{29}$ Manusia satu dengan manusia lain dapat terikat satu dengan yang lain dalam suatu ikatan yang memberikan akibat hukum kepada para pihak yang dapat dilakukan melalui sebuah kontrak.

Walter Woon dalam bukunya Basic Business Law in Singapore, sebagaimana dikutip oleh Ridwan Khairandy menyatakan bahwa, di dalam sistem Common Law ada pembedaan antara contract dan agreement. Semua Kontrak adalah agreement, tetapi tidak semua agreements

${ }^{29}$ R. Subekti, Hukum Perjanjian, PT. Intermasa, Jakarta, 1987, hlm. 1. 
adalah Kontrak. ${ }^{30}$ Hukum kontrak semata-mata dimaksudkan sebagai hukum yang mengatur tentang perjanjian-perjanjian yang prestasinya dilakukan oleh kedua belah pihak. Untuk sekedar membedakan dari perjanjian yang prestasinya dilakukan oleh satu orang (perjanjian sepihak) misalnya perjanjian yang timbul dari lapangan hukum keluarga, yaitu perjanjian hibah dan perjanjian warisan.

Pasal 1313 KUHPerdata memberikan pengertian perjanjian sebagai suatu perbuatan yang terjadi antara satu orang atau lebih mengikatkan dirinya terhadap orang lain. Pasal ini memberikan bukti bahwa sebetulnya perjanjian adalah sebagai agreement yang juga merupakan kontrak, tetapi ada kontrak, khususnya perjanjian dua pihak yang kemudian tidak dapat dimasukkan dalam pengertian pasal 1313 KUHPerdata tersebut. Bukti berikutnya bahwa tidak selalu kontrak sama dengan agreement adalah dikenalnya istilah kebebasan berkontrak yang lebih populer dalam praktek dan tidak lazim dikatakan sebagai kebebasan berperjanjian.

Dalam upaya mempertegas definisi perjanjian sehingga mencakup baik perjanjian sepihak atau dua pihak, maka Pasal 6:213 ayat (1) Kitab Undang-Undang Hukum Perdata Belanda (BW Baru) memberikan batasan perjanjian sebagai suatu perbuatan hukum yang terjadi antara satu orang atau lebih mengikatkan dirinya kepada satu orang atau lebih dimana keduanya saling mengikatkan dirinya.

Perjanjian lahir jika disepakati tentang hal yang pokok atau unsur esensial dalam suatu kontrak. Penekanan tentang unsur yang esensial tersebut karena selain unsur yang esensial masih dikenal unsur lain dalam suatu perjanjian.

Mengenai Unsur-unsur dari suatu perjanjian dapat dikaji dari dua sudut pandang yaitu: ${ }^{31}$ Pertama, Dilihat dari pengertian perjanjian. Apabila kita melihat kembali didalam KUHPerdata maka kita akan dapat menemukan definisi dari perjanjian tersebut pada pasal 1313 yang mengatur: "Suatu persetujuan adalah suatu perbuatan dimana satu orang atau lebih mengikatkan diri terhadap satu orang lain atau lebih" Berdasarkan ketentuan pasal diatas maka disimpulkan bahwa yang dimaksud dengan perjanjian itu adalah suatu persetujuan yang dengan mana saling mengikatkan diri didalam hal-hal yang berkaitan dengan hak dan kewajiban yang dimiliki oleh masing-masing pihak yang telah saling mengikatkan diri tersebut, atau dengan kata lain hal-hal yang menjadi esensi dari suatu perjanjian itulah yang juga menjadi unsur dari suatu perjanjian berdasarkan pengertiannya. Oleh karena itu dari kesimpulan perjanjian tersebut maka dapat pula ditarik kesimpulan bahwa Unsur-unsur perjanjian berdasarkan pengertian perjanjian adalah: Ada pihak-pihak sedikitnya dua orang, Ada persetujuan antara pihak-pihak itu, Ada tujuan yang hendak dicapai, Ada prestasi yang dilaksanakan, Ada bentuk tertentu, Ada syarat-syarat tertentu.

Kedua, Dilihat dari syarat-syarat perjanjian. Apabila dilihat dari syarat-syarat perjanjian maka dapat ditarik kesimpulan bahwa unsur-unhsur perjanjian itu terdiri atas 3 jenis yaitu:

\section{a. Unsur Essentialia}

Ini adalah unsur yang harus mutlak ada didalam suatu perjajian dimana tanpa adanya unsur ini maka perjajian tidak akan dianggap penah ada, unsur ini adalah unsur yang yang mempunyai sifat essesial yang menyebabkan teciptanya perjanjian, mengenai apa saja unsur essential ini dapat dilihat pada pasal 1320 KUHPerdata yang juga merupakan Syarat sahnya dari suatu perjanjian

b. Unsur naturalia

${ }^{30}$ Ridwan Khairandy, Iktikad Baik dalam Kebebasan Berkontrak, Program Pascasarjana Fakultas Hukum Universitas Indonesia, Jakarta, Cetakan Kedua, 2004, hlm.43

${ }^{31}$ M Zen Abdullah, Kajian Yuridis Terhadap Syarat Sah dan Unsur-Unsur dalam suatu Perjanjian, Universitas Batanghari, tanpa tahun. 
Yang dimaksud dengan unsur naturalia ini adalah unsur yang lazim melekat pada perjajian sekali pun unsur ini tidak dimasukkan kedalam perjanjian ia tetap melekat didalam perjanjian.

\section{c. Unsur Accidentalia}

Adalah Unsur yang secara tegas dan jelas di sebutkan didalam perjanjian, dengan kata lain unsur ini adalah unsur yang menjadi isi dari suatu perjanjian.

Dalam Pasal 18 UUHC, sejatinya telah memiliki unsur esensialia dan unsur ini merupakan unsur yang harus ada dalam suatu perjanjian karena tanpa adanya kesepakatan tentang unsur esensial ini maka tidak ada perjanjian. Dalam kontrak jual putus berdasarkan Pasal 18 UUHC tersebut harus ada kesepakatan mengenai perlalihan kepemilikan Hak Cipta Pengarang dan harga yang harus dibayarkan oleh penerbit karena tanpa kesepakatan mengenai Hak Ekonomi dan harga dalam kontrak jual putus tersebut, perjanjian tersebut batal demi hukum karena tidak ada hal tertentu yang diperjanjikan. Menyangkut unsur esensialia berupa benda, berarti bahwa posisi penjual, dijadikan prioritas kerena benda itu merupakan bahan ramuan pokok kehidupan manusia sebagai anggota masyarakat. ${ }^{32}$ Bahwa kewajiban setelah terjadi kesepakatan tentang Barang dan Harga dalam perjanjian Jual Putus, maka berlaku pula kewajiban penjual untuk segera menyerahkan naskah asli (manuskrip) dari buku tersebut kepada Penerbit.

Terkait unsur naturalia merupakan unsur yang telah diatur dalam undang-undang sehingga apabila tidak diatur oleh para pihak dalam kontrak, maka mengikuti ketentuan yang diatur dalam undang-undang tersebut, sehingga unsur naturalia ini merupakan unsur yang selalu dianggap ada dalam kontrak jual putus. Misalnya, bagaimana jika ciptaan yang dibeli itu kemudian didiamkan saja oleh pembeli? Apakah Pembeli boleh untuk tidak diproduksi secara masal untuk menikmati hak ekonominya? Apakah si penjual dapat secara otomatis membatalkan perjanjian jual putus itu sebelum masa berlaku perjanjian selama 25 tahun itu berakhir. Pertanyaan-pertanyaan tersebut secara sistematis menjadi menjadi bagian dari unsur naturalia dalam suatu perjanjian. Sebuah unsur yang merupakan ketentuan hukum umum, suatu syarat yang biasanya dicantumkan dalam perjanjian. Namun hal tersebut belum diatur dalam UU di Indonesia. Sebagai contoh, di Belanda klausula-klausula yang diatur dalam UU kontrak Hak Cipta Tahun 2015 yaitu Klausula Non Use dalam Perjanjian Jual Putus.

Unsur-unsur atau hal ini biasanya dijumpai dalam perjanjian-perjanjian tertentu, dianggap selalu ada kecuali dinyatakan sebaliknya. Contoh dalam hukum perjanjian di Indonesia, jika kluausla tersebut dalam kontrak tidak diperjanjikan tentang cacat tersembunyi, secara otomatis berlaku ketentuan dalam BW bahwa penjual yang harus menanggung cacat tersembunyi.

Sedangkan berkaitan unsur aksidentalia merupakan unsur yang akan ada atau mengikat para pihak jika para pihak memperjanjikanya. Apakah perjanjian jual putus bisa diatur menyimpang dari ketentuan Pasal 18 UUHC, sebagaimana menjadi kehendak para pihak? Hal-hal yang diatur secara khusus menyimpang melalui klausul-klausul dalam perjanjian, yang merupakan unsur accidentalia. Unsur yang memungkinkan adanya atau diaturnya klausula menyimpang dan sebaliknya bisa juga tidak diatur, semuanya bergantung pada keinginan para pihak, merasa perlu untuk memuat ataukah tidak dengan tujuan melengkapi keberadaan unsur essensialia dan unsur naturalia. Kesepakatan tentang ketentuan-ketentuan apa saja inilah yang harus diperjuangkan secara bebas untuk disepakati baik oleh Pencipta buku ataupun Pembeli Hak Cipta secara seimbang.

\footnotetext{
${ }^{32}$ Moch. Isnaeni, Perjanjian Jual Beli, Refika Aditama, Bandung, 2016, hlm. 82
} 
Pengalihan Hak Cipta melalui Perjanjian Jual Putus, memberikan konsekunsi yang serius dimana kedudukan penerima hak menjadi pemilik hak cipta dan dengan demikian dapat mengalihkan hak cipta secara bebas. Untuk kepentingan perlindungan yang seimbang, maka membutuhkan di dalam Perjanjian Jual Putus Hak Cipta terdapat klausulaklausula yang kurang lebih seragam substansinya. Selain didalam kontrak, maka ideal dimasukkan di dalam Peraturan Pelaksanaan Pasal 18 UUHC dimana harus diatur satu pasal yang memuat klausula tersebut.

Pada intinya, sejatinya perlu diadakan ketentuan-ketentuan yang mengatur ruang lingkup klusula-klausula dalam kontrak pengalihan Hak Cipta yang bertujuan untuk melindungi Pencipta yang berlaku. Untuk kepentingan penyusunan ketentuan yang mengatur ruanglingkup klausula dalam perjanjian jual putus maka dalam penelitian ini coba dilakukan pengumpulan konsep-konsep pengaturan ruang lingkup Perjanjian Jual Putus secara rinci dan sifatnya pasti dan memaksa dan harus dipatuhi oleh setiap pembuatan perjanjian Jual Putus Hak Cipta yang berlaku di negara yang sudah kokoh hukum Hak Cipta nya. Misalnya: Penentuan ruang lingkup hak: Sejumlah negara telah memperkenalkan ketentuan kontrak wajib dalam undang-undang hak cipta mereka untuk memastikan bahwa kontrak menentukan secara lebih tepat ruang lingkup dan ketentuan hak yang dialihkan, sehingga mencegah penulis menandatangani kontrak kosong dalam mentransfer hak mereka . Bergantung pada negaranya, aturan tersebut dapat mencakup: (1) kewajiban umum untuk secara kontrak dan tepat menentukan hak dan mode eksploitasi yang diberikan / Berlisensi; (2) kewajiban untuk menentukan ruang lingkup geografis dan durasi pengalihan hak; (3) larangan untuk mengesampingkan atau mengalihkan beberapa hak untuk remunerasi; (4) beberapa batasan untuk mengalihkan hak dalam pekerjaan masa depan; (5) larangan atau pembatasan untuk mengalihkan hak dalam bentuk eksploitasi yang belum diketahui; (6) pembatasan pengalihan hak moral. ${ }^{33}$

Indonesia harus konsisten untuk mengatur lebih rinci dalam sebuah Peraturan Pelaksana UUHC terkait ketentuan Pasal 18 UUHC, yang mengatur hal ikhwal ketentuanketentuan yang bertujuan untuk melindungi para pihak dalam Perjanjian Jual Putus dengan melakukan pengaturan secara rinci sifatnya, pasti dan memaksa harus dipatuhi oleh setiap pembuatan perjanjian Hak Cipta. Walaupun ini tidak mudah, dikarenakan perjanjian jual putus adalah perjanjian jenis baru yang juga hanya dimunculkan dalam satu pasal dalam UUHC, maka merinci klausula-klausula apa sajakah yang paling sedikit harus ada dalam perjanjian jual putus tersebut, antara lain:

(1). Judul

(2). nama dan alamat para pihak;

(3). schope Pengalihan Hak Cipta;

(4). hak dan kewajiban para pihak;

(5). Pengertian dan Model pemindahan hak (termasuk isu hak moral),

(6). Bentuk dan formalitas yang dipersyaratkan,

(7). pembatasan pengalihan hak,

(8). kewajiban untuk menentukan cakupan,

(9). Jangka Waktu perjanjian

(10). ruang lingkup wilayah;

(11). Pendapatan Penulis (remunerasi) dalam pengalihan Hak Cipta,

(12). kewajiban eksploitasi yang dikenakan kepada orang yang memperoleh hak,

(13). Larangan Transfer kedua;

(14). penyelesaian sengketa; dan

${ }^{33}$ https://www.europarl.europa.eu/meetdocs/2009_2014/documents/juri/dv/contractualarangem ents_/contractualarangements_en.pdf diakses 12 Desembver 2020. 
(15). tata cara perpanjangan, pengakhiran, dan pemutusan perjanjian.

(16). peraturan interpretasi, dan

(17). penghentian atau revisi kontrak setelah 25 Tahun.

(18). Dll

Peraturan-peraturan tersebut, akan sangat bermanfaat untuk mengatasi persoalan hukum jika ada perjanjian tertulis yang dibuat dengan obyek selain karya tulis dan lagu atau bahkan juga bisa berlaku terhadap karya tulis dan lagu, khususnya jika ada penerbit yang tidak segera menerbitkan naskah asli pengarang menjadi buku.

Selain perilaku-prilaku pembuatan kontrak penerbitan yang lama, maka pada era digital sekarang, pengalaman-pengalaman lama di dalam kontrak telah bergeser dinamis. Menentukan beberapa kesepakatan kontrak untuk jangka waktu tak terbatas atau tidak dibatasi waktunya tampaknya sekarang juga menjadi pilihan. Lebih jauh lagi, perusahaan penerbitan di era persaingan ini kemudian lebih realistis dengan menerbitkan buku-buku lama dari pada bekerjasama dengan pengarang-pengarang baru, kecuali mereka mau mengalihkan Hak Cipta semuanya kepada Penerbit. ${ }^{34}$

Perjanjian tidak mampu lagi mempertahankan perilaku-perilaku lama di Industri penerbitan, banyak hal-hal yang baru muncul dalam mensikapi pertumbuhan teknologi informasi di dunia penerbitan dengan resiko-resiko ekonomi yang semakin meningkat. Penerbit semakin dapat memperkirakan apakah buku yang diterbitkan akan disukai oleh masyarakat dengan mensurvey terlebih dahulu menggunakan teknologi digital, sehingga Pengarang sering tidak mampu mengikuti perubahan perilaku Penerbit ini dalam mengambil keputusan untuk tidak menggunakan (non use) naskah asli setelah perjanjian ditandatangani untuk diterbitkan menjadi buku.

Permasalahan diatas yang menimpa perjanjian-perjanjian baku atau sudah dibakukan dalam pengalaman penerbitan, mengharuskan Perusahaan Penerbitan dan juga Pengarang merespon adanya perkembangan zaman. Perubahaan-perubahan eksternal di luar perjanjian penerbitan dapat diatasi oleh asas-asas dalam perjanjian, misalnya asas kebebasan berkontrak, asas konsensual, asas itikad baik. Asas-asas tersebut sebetulnya sudah menampung solusi bagi problematika-problematika yang muncul karena perubahan peristiwa kongkrit.

Terhadap berkembangnya persoalan-persoalan dalam praktek Perjanjian Jual beli khusunya terkait dalam permasalahan penelitian ini, maka penting juga untuk memasukkan klausula yang juga sudah masuk dalam Uundang-Undang Hukum Kontrak Hak Cipta Belanda tahun 2015, yaitu: Klausula Non Use.

Pengarang mengalihkan Hak Cipta kepada Penerbit adalah dengan tujuan agar dieksploitasi melalui industry penerbitan, sehingga jika Penerbit hanya sekedar membeli karya Cipta dari Pengarang tanpa upaya untuk dipublikasikan kepada masyarakat, maka dalam kontrak seharusnya juga diantisipasi dengan mengatur klausula non use (klausula tidak dipergunakan). Antisipasi terhadap persoalan tersebut dapat menggunakan ketentuan di Belanda, sebagaimana ketentuan yang telah diatur dalam Artikel 25e Undang-Undang Kontrak Hak Cipta tanggal 1 Juli 2015, yaitu: Pasal 25e [tidak digunakan]:

1. Pencipta dapat membubarkan kontrak selurubnya atau sebagian jika pibak lain dalam kontrak. tidak. cukup mengeksploitasi hak. cipta atas kary a dalam jangka waktu yang wajar setelah pembuatan kontrak, atau tidak mengeksploitasi hak cipta secara memadai setelah sebelumnya melakukan tindakan eksploitasi. Kalimat sebelumnya tidak akan berlaku jika kegagalan untuk mengeksploitasi hak cipta secara memadai dalam periode ini disebabkan oleh penciptanya, atau jika kepentingan pihak lain pada kontrak dalam mempertahankan kontak begitu memaksa sehingga, sesuai dengan standar kewajaran dan keadilan, itu melebihi minat penciptanya dalam hal itu.

${ }^{34}$ wawancara tanggal 7 November 2020 
2. Jika hak cipta diberikan pada beberapa pembuat dan kontribusi pembuat tidak berbeda dengan kontribusi pembuat lainnya, maka pembuat hanya dapat membubarkan kontrak dengan persetujuan dari pembuat lainnya. Jika pembuat tidak memberikan persetujuannya dan pembuat lainnya mengalami kerugian secara tidak proporsional sebagai akibatnya, kontrak hanya dapat dibubarkan oleh pengadilan.

3. Sejauh eksploitasi oleh pihak lain terhadap kontrak tidak mustahil secara permanen, hak untuk membubarkan kontrak hanya akan muncul setelah pembuatnya memberikan pihak lain, secara tertulis, jangka waktu yang wajar untuk cukup mengeksploitasi pekerjaan dan tidak ada eksploitasi dilakukan dalam periode ini.

4. Atas permintaan pembuat, pihak lain dalam kontrak harus memberinya pernyataan tertulis tentang tingkat eksploitasi dalam batas waktu yang dimaksud di paragraf ketiga.

5. Sesuai dengan Pasal 6: $267 \mathrm{KUH}$ Perdata, kontrak harus dibubarkan dengan pernyataan tertulis oleh pembuat kepada pihak lain dalam kontrak. Atas penerapan oleh pembuat, kontrak juga dapat dibubarkan oleh keputusan yudisial.

6. Jika pihak lain dalam kontrak telah menyerahkan hak ciptanya kepada pihak ketiga, maka pembuat juga dapat menggunakan hak yang timbul dari pembubaran terhadap pihak ketiga tersebut setelah memberitahukan pembubaran tersebut, secara tertulis, secepat mungkin.

7. Jika pihak lain dalam kontrak atau pihak ketiga tidak mentransfer kembali hak cipta dalam jangka waktu yang ditentukan secara wajar, maka pengadilan dapat, atas permohonan pembuatnya, menentukan jumlah yang wajar dalam keadaan di mana pihak lain dalam kontrak tersebut atau pihak ketiga harus membayar pembuat, selain kerusakan yang harus dibayar kepada pembuat.

Akhirnya, solusi perundang-undangan dapat merujuk dengan apa yang dilakukan oleh India, dimana dengan tegas mengatasi persoalan Penerbit hanya sekedar membeli karya Cipta dari Pengarang tanpa upaya untuk dipublikasikan kepada masyarakat maka perjanjian harus segera diakhiri. Where the assignee fails to exercise his rights within one year from the date of assignment, the assignment in respect of such right shall be deemed to have lapsed, unless otherwise specified in the assignment deed. [vide Section 19(4) of the Act] (Apabila penerima hak gagal melaksanakan haknya dalam waktu satu tahun sejak tanggal penugasan, penugasan sehubungan dengan hak tersebut dianggap telah lewat, kecuali dinyatakan sebaliknya dalam akta penugasan. [vide Bagian 19 (4) Undang-Undang]).

\section{E. PENUTUP}

Konsep peralihan kepemilikan hak cipta buku melalui Perjanjian jual Putus pada Sistem Hukum Hak Cipta Indonesia yang hanya diatur dalam Pasal 18 UUHC jelas belum memberikan ketentuan klausula Non Use. Secara substansi hukum, Para pihak dapat mengaturan peralihan Hak Cipta melalui Perjanjian Jual Putus yang disepakati dan ditandatangani para pihak. Namun dalam praktek, perjanjian yang telah dibuat sama sekali juga tidak mencantumkan klausula Non Use tersebut. Jika terjadi sengketa pelaksanaan perjanjian Jual Putus, dimana Pengarang melakukan klaim diberlakukannya klausula Non Use terhadap Penerbit yang mendiamkan manuskrip dalam keadaan semula, maka Pengadilan dapat menggunakan asas-asas perjanjian, kepantasan dan kebiasaan sebagaimana diatur dalam Pasal 1339 KUH Perdata Jo. Pasal 1601 KUH Perdata, sebelum 
lahir peraturan perundang-undangan khusus tentang Hukum Kontrak Hak Cipta Indonesia.

Rekonseptualisasi Peralihan kepemilikan hak cipta buku melalui Perjanjian Jual Putus dalam ketentuan Pasal 18 Undang-Undang Hak Cipta Indonesia yang belum memberikan perlindungan hukum yang optimal bagi para pihak, maka secara yuridis dapat diusulkan rekonseptualisasi Pasal 18 UUHC yang direvisi sebagai berikut: "Ciptaan buku, dan/atau semua hasil karya tulis lainnya, lagu dan/atau musik dengan atau tanpa teks yang dialihkan dalam perjanjian jual putus dan/atau pengalihan tanpa batas waktu, yang muatan isinya diatur dalam perjanjian yang dibuat diantara para pihak dengan ketentuan tentang tata cara pembuatan dan klausula-klausula yang harus dimuat diatur lebih lanjut dalam Peraturan Pemerintah".

Rekonsepsi pengaturan peralihan kepemilikan Hak cipta buku melalui Perjanjian jual Putus pada Sistem Hukum Hak Cipta Indonesia adalah Pengaturan yang harus dapat diberlakukan dan tidak memiliki benturan konsep atau asas sehingga dapat memberikan perlindungan hukum secara komprehensif dan sistematis secara substansi hukumnya, sturktur hukum dan budaya hukum

\section{DAFTAR PUSTAKA}

Elyta Ras Ginting, Hukum Hak Cipta Indonesia Analisis dan Praktik, Jakarta, Citra Aditya Bakti, 2012

JJ.H. Bruggink, Rechts-reflecties diterjemahkan oleh Arief Sidharta, Refleksi Tentang Hukum, Pengertian-Pengertian Dasar dalam Teori Hukum, Cetakan ketiga, Citra Aditya Bakti, Bandung 2011

Mattulada, Studi Islam Kontemporer (Sintesis Pendekatan Sejarah, Sosiologi dan Antropologi dalam Mengkeaji Fenomena Keagamaan), dalam Taufik Abdullah dan M. Rusli (ed), Metodologi Penelitian Agama Sebuah Pengantar, Tiara Wacana,Yogyakarta, 1990

Munir Fuady, Metode Riset bukum, Pendekatan Teori dan Konsep, Rajawali Pers, Depok, 2018

Mukti Fajar, Dualisme Penelitian Hukum Normatif \& Empiris, Pustaka Pelajar, Yogyakarta, 2010

M Zen Abdullah, Kajian Yuridis Terbadap Syarat Sah dan Unsur-Unsur dalam suatu Perjanjian, Universitas Batanghari.

Moch. Isnaeni, Perjanjian Jual Beli, Refika Aditama, Bandung, 2016.

Nasikun, "Hukum dalam Paradigma Sosial', dalam Artidjo Alkostar (ed), Identitas Hukum Naisonal, Yogyakarta, Fakultas Hukum UII, 1997.

Setiono, Pemahaman Terbadap Metodologi Penelitian Hukum, Pogram Studi Ilmu Hukum Pascasarjana Universitas Sebelas Maret Surakarta, 2010

Paul Scholten dalam Satjipto Rahardjo, Imu Hukum, Bandung, Penerbit PT Citra Aditya Bakti, 2012

Walter Woon, Basic Business Law in Singapore, Prentice Hall, New York, 1995

Naskah aslinya menyebutkan : "Een overeenkomst in de rijn van dze titel isn een meerrijdige rechtshandeling, waarbij een of meer partijen jegens een of meer andere een verbintenis aangaan" Lihat R.J. Q Klomp (red), Burgerlijk Wetboek, Boken 1 t/m 8, Ars Aequi Libri, nijmegen, 1997.

Sutan Remy Sjahdeini, Kebebasan berkontrak dan Perlindungan yang Seimbang bagi Para Pibak dalam Perjanjian Kredit Bank di Indonesia, Jakarta, IBI, 1993

Pandangan ini persis sama dengan yang terkandung dalam Restatement Second, Section 25. Dalam penjelasan nya dikatakan: "every contract imposes upon each party a duty of good faith and fair dealing in its performance and enforcement". Sebagaimana dijelaskan oleh 
Ridwan Khaerandy dalam "Kemerosotan supremasi kebebasan berkontrak", makalah, tanpa tahun.

Cacat kehendak di atas menurut J. Satrio, Perikatan yang Labir dari perjanjian, Buku I Citra Aditya Bakti, Bandung, 1995, hlm. 164. lihat juga Mariam Darus Badrulzaman, Aneka Hukum Bisnis, Alumni, Bandung, 1994

R. Subekti, Hukum Perjanjian, PT. Intermasa, Jakarta, 1987

Ridwan Khairandy, Iktikead Baik dalam Kebebasan Berkontrak, Program Pascasarjana Fakultas Hukum Universitas Indonesia, Jakarta, Cetakan Kedua, 2004 